\title{
A comemoração do 21 de abril: o cenário do jogo político (1930-1960)
}

Thais Nivia de Lima e Fonseca*

Resumo. Celebrações cívicas e estímulos aos sentimentos patrióticos são especialmente úteis e eficazes no jogo político, pois lidam com a história e com a memória, podendo estar no centro de lutas pelo poder. A festa cívica, também um lugar de memória, dedica-se, antes de tudo, à exaltação da nacionalidade, o que faz com que, na maioria das vezes, o seu principal objeto seja a comemoração de um episódio ou de um personagem visto como significativo na história da nação. Este artigo trata das festas de 21 de abril, dedicadas à memória da Inconfidência Mineira e de Tiradentes, em Minas Gerais e no Rio de Janeiro, entre 1930 e 1960, quando se tornaram instrumento de propaganda e mecanismo de legitimação, principalmente nos períodos dos governos de Getúlio Vargas e de Juscelino Kubitschek.

Palavras-chave: Festa cívica. Propaganda. Inconfidência Mineira.

* Doutora em História Social. Universidade Federal de Minas Gerais.

Anos 90, Porto Alegre, v. 12, n. 21/22, p.437-486, jan./dez. 2005 
A comemoração do 21 de abril: o cenário do jogo político (1930-1960)

\begin{abstract}
As comemoraçoes de Tiradentes tiveram, ontem, um sabor todo especial de anacronismo. Quem mais se constrangeu, ao lembrar a figura do indiscreto dentista mineiro, foi por certo o sr. Presidente da República. S. exc., se lhe fosse dado, a apostar em como teria transferido "sine die" a celebração da Inconfidência, que veio, por ironia do calendário, justamente no momento mais impróprio que imaginar se pudesse... O sr. Washington Luis, se não tivesse que render hipócritas homenagens à virtude, apearia dos seus monumentos ao pobre enforcado de 21 de abril, para lhe por no lugar a Joaquim Silvério dos Reis.
\end{abstract}

Rubens do Amaral, 1930

A julgar pelos comentários do jornalista do Diário de São Paulo, deve ter sido grande o constrangimento do presidente Washington Luís, instado pelas obrigações que lhe impunham o cargo, a participar das comemorações de uma efeméride que lhe lembraria um dos estados dissidentes do arranjo político da época e os conflitos daí decorrentes. A percepção desse constrangimento serviu para que o comentarista tecesse analogias entre o fato comemorado e o momento político vivido. Melhor dizendo, ele aproveitou-se das possibilidades de comparações entre os personagens das tramas, jogando com as avaliações que fez do caráter de cada um deles. O dia da morte de Tiradentes já era comemorado desde o final do século XIX, e apesar de ainda caro aos republicanos, em 1930 não havia sido instituída uma tradição celebrativa mais firme, como ocorreria depois da chegada de Getúlio Vargas ao poder. No entanto, apesar, ou por causa mesmo do delicado momento vivido naquele ano, o presidente da República não se furtou à cerimônia.

Celebrações cívicas e estímulos aos sentimentos patrióticos são especialmente úteis e eficazes no jogo político, pois lidam com a história e com a memória, que, como afirma Eliana Dutra (1994, p.78), 
[...] vão estar sempre no centro das lutas que socialmente se travam pelo poder, onde o controle do passado e a autoridade da tradição são sempre condição necessária para legitimar as dominações e também as contestações do presente.

Numa perspectiva mais geral, as festas são vistas como momentos propícios à afirmação de identidades, crenças e valores, à rememoração de tradições, à legitimação de hierarquias sociais. No que diz respeito às festas cívicas, de caráter político, algumas

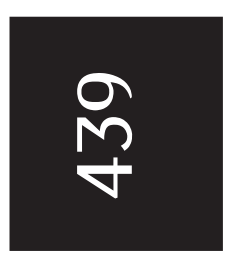
dessas funções aparecem como mais evidentes, e sua análise ajuda na compreensão de sua manutenção por longo período, bem como de suas transformações no tempo. A festa cívica, também um lugar de memória, dedica-se, antes de tudo, à exaltação da nacionalidade, o que faz com que, na maioria das vezes, o seu principal objeto seja a comemoração de um episódio ou de um personagem visto como significativo na história da nação.

Como comemoração de episódios da história da nação, as festas cívicas tornam-se os momentos privilegiados para a celebração de uma certa comunhão da comunidade nacional, simbolizada nos rituais que envolvem a participação real ou imaginada de vários segmentos da sociedade; nos discursos que exaltam a nação como o resultado de lutas ancestrais; na afirmação da crença na coesão, na conjunção de interesses e no espírito de coletividade. Essas comemorações não são, como bem lembrou Philippe Raynaud (1994), exclusivamente legitimadoras de uma unidade, mas podem, elas mesmas, trabalhar para produzi-la. Elas têm, além disso, um forte caráter pedagógico, uma vez que os eventos e os vultos do passado são evocados como modelos para o presente, memória da qual a nação não pode prescindir, pois é nela que busca os elementos que a explicam e a legitimam.

Organizadas de uma maneira geral pelo Estado ou por grupos políticos e sociais dominantes, as festas cívicas carregam as cores de seus organizadores e traduzem seus interesses e projetos.

Anos 90, Porto Alegre, v. 12, n. 21/22, p.437-486, jan./dez. 2005 
A comemoração do 21 de abril: o cenário do jogo político (1930-1960)

Isso não significa dizer que haja unanimidade sobre elas, que sejam aceitas tal e qual são concebidas, que sua recepção seja unívoca e que seus resultados sejam sempre os esperados por seus promotores. A festa cívica trabalha em favor da unidade, mas deixa aflorar as dissensões. Em muitos casos não há consenso nem quanto ao objeto da própria comemoração. Em outros, a unanimidade resume-a a ele, entrando-se em luta por sua posse. Sob certo ponto de vista, esse é o caso da comemoração da Inconfidência Mineira e, sobretudo, da celebração de Tiradentes, ao lado do qual se perfilam as mais variadas tendências políticas, todas reivindicando os direitos de sua evocação. Todas procurando apropriar-se de suas representações como bandeiras de seus projetos e posições, vendo-o como útil instrumento de legitimação.

O jogo de poder presente nas festas cívicas tem espaço determinado para acontecer, no sentido físico mesmo. É onde o teatro da política se instala, para que os símbolos e as representações atuem, e sua escolha não é aleatória nem neutra. Esses lugares são revestidos de funções simbólicas e de referências fundamentais para a legitimação da festa em si e dos que a promovem, e no caso da comemoração exaltadora de eventos e heróis, eles tornam-se, também, espaços sacralizados nos quais os traços do religioso impregnam o político. As festas de 21 de abril sempre estiveram ligadas a esses espaços, sacralizados pela exaltação patriótica eivada de elementos religiosos, em suas referências simbólicas e em seus discursos. Na criação e organização das comemorações analisadas neste texto, no Rio de Janeiro e em Minas Gerais, os cenários foram cuidadosamente escolhidos, esquadrinhados quase arqueologicamente, em busca de tudo aquilo que, relacionado à trajetória de Tiradentes, pudesse valorizar a festa. E alguns dos lugares havidos como mais significativos foram escolhidos para cenários da comemoração.

No Rio de Janeiro, a praça defronte ao Palácio Tiradentes, a antiga Cadeia Velha onde Tiradentes ficara preso; a rua da Assem-

Anos 90, Porto Alegre, v. 12, n. 21/22, p.437-486, jan./dez. 2005 
bléia, antiga rua da Cadeia; o Largo da Carioca e a rua da Carioca, por onde passara o cortejo da execução; a Igreja da Lampadosa, onde Tiradentes teria parado por instantes; a Praça Tiradentes, onde teria ficado o cadafalso. Se no Rio de Janeiro ressaltava o cenário da morte, Ouro Preto despontava como o locus da conspiração, da elaboração dos planos, do sonho da independência. E na cidade, a Praça Tiradentes seria o seu espaço mais sagrado. Centro político-administrativo da antiga Vila Rica, a Praça concentrava, na segunda metade do século XVIII, os espaços consagrados dos

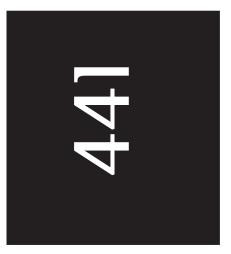
principais poderes da época, como o Palácio dos Governadores, o Senado da Câmara e Cadeia Pública. Já temos aí os lugares próprios de vários dos principais personagens desse episódio, dos representantes do poder metropolitano, dos traidores, dos conspiradores e depois réus. Finalmente, a Praça tornou-se também o espaço do herói, quando sua cabeça decepada foi aí exposta em "poste de ignomínia".

Essas considerações são importantes balizas na análise da comemoração do 21 de abril como o cenário do jogo político, privilegiando-se dois momentos de sua existência. Neles pode-se perceber nuanças das apropriações das representações já consolidadas de Tiradentes e da Inconfidência, no jogo de construção de representações que legitimam seus próprios apropriadores. $\mathrm{O}$ primeiro momento corresponde ao período do governo de Getúlio Vargas (1930-1945), período de reassentamento das forças políticas após a Revolução de 1930 e da consolidação do processo de centralização do poder, com a instalação e vigência do Estado Novo. O segundo momento corresponde ao período da passagem de Juscelino Kubitschek pelos governos de Minas Gerais e do Brasil (1951-1955 e 1956-1961, respectivamente), quando o projeto desenvolvimentista buscou efusivamente no passado sua legitimação. Para a análise da comemoração nesses dois momentos, a imprensa escrita foi a principal fonte utilizada, por representar um instrumento de ligação entre a festa, seus executores e o público. 
A comemoração do 21 de abril: o cenário do jogo político (1930-1960)

O Estado sempre foi elemento chave das comemorações de 21 de abril, sobretudo no Rio de Janeiro, desde a instalação da República, em 1889. No entanto, as iniciativas partiam, inicialmente, de entidades representativas de grupos políticos, associações profissionais ou outros, que acabaram por imprimir à celebração algumas particularidades que a acompanharam até o final do Estado Novo. Essa forma de inserção do Estado manteve-se por algum tempo após 1930, uma vez que, apesar da supressão do feriado nacional por um decreto do governo provisório, a comemoração continuaria a acontecer. ${ }^{1}$ Seguiu a tradição iniciada com os antigos republicanos, e a cada aniversário da morte de Tiradentes reuniam-se seus cultores nas escolas, nas igrejas e associações católicas, nos institutos históricos, nos clubes e associações patrióticas, nos grupos de escotismo, nas associações comerciais e profissionais, nos clubes e academias literárias. Em todas as cidades onde ocorriam comemorações, representantes do governo e autoridades locais eram convidados, ocupando lugares de destaque, fazendo discursos, distribuindo elogios. A comemoração articulava-se melhor no Rio de Janeiro, onde ainda era forte a herança dos clubes republicanos, e onde mantinha-se a tradição, iniciada no século XIX, da reconstituição do cortejo da execução de Joaquim José, que ia do Palácio Tiradentes (antiga Cadeia Velha) até a Praça Tiradentes (antigo Campo da Lampadosa).

A partir de 1932, a presença do governo foi se firmando, acompanhando o processo de centralização e de uma maior intervenção do Estado nas várias dimensões da vida do país. No bojo de um projeto centralizador e unitarista, as festas cívicas assumiriam importante papel. Naquele mesmo ano, quando era comemorado o $140^{\circ}$ aniversário da morte de Tiradentes, registrou-se uma participação mais nítida do governo, não apenas por meio do controle da utilização do espaço público, mas principalmente pela mediação na mobilização de vários segmentos que deveriam tomar parte na festa, a ser realizada no Rio de Janeiro. A organização 
do evento estava a cargo da Comissão Glorificadora do Protomártir da Independência que, ao planejar um grande préstito cívico, buscava reconstituir o trajeto percorrido por Tiradentes até a forca, culminando com o lançamento da pedra fundamental do Templo Cívico à Memória de Tiradentes, a ser construído no local. Com o apoio do governo provisório, a Comissão Glorificadora expediu convites a todos os estados brasileiros, que trataram de estendê-los internamente. Resultado disso foi a adesão numerosa à celebração, chegada de várias partes do país, e o envio de representantes para a

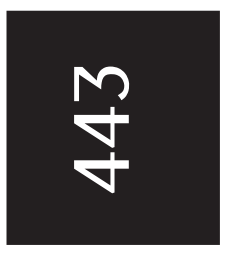
festa. A capacidade de mobilização nesse momento mostrou-se inédita em relação às comemorações anteriores, das quais temos notícias esparsas, localizadas, raramente integradas como a que ficou registrada em 1932. ${ }^{2}$ Além de facilitar as comunicações do Rio de Janeiro com outras partes do Brasil por meio dos interventores estaduais, o governo provisório ainda providenciou para que a participação da população do Rio de Janeiro na festa fosse expressiva. Para isso sua atuação foi significativa no âmbito das forças militares, das escolas e dos órgãos públicos em geral, o que já apontava para o que seriam os pilares de sustentação da propaganda utilizada, mais intensamente, após o golpe de 1937.

Todos os principais segmentos militares da capital federal foram convocados a participarem do préstito cívico, no qual teriam importante papel na execução do ritual comemorativo, desde a formação das guardas por todo o trajeto da procissão reconstituindo a situação no cortejo de 1792 - até a execução de hinos pelas bandas militares e o lançamento de salvas de tiros das fortalezas e dos navios de guerra ancorados no porto da cidade. Enquanto isso, uma esquadrilha de mais de 30 aviões lançaria flores sobre o local da celebração. Todo esse ritual teria momento certo para acontecer, às 11 horas da manhã, marcando simbolicamente o horário da morte do homenageado. Numa antecipação daquilo que pautaria a atuação do Ministério da Educação nos projetos de formação cívica da nação, até 1945, o então ministro 
A comemoração do 21 de abril: o cenário do jogo político (1930-1960)

Francisco Campos encarregou-se das providências que seriam tomadas pelo governo, principalmente no tocante à mobilização dos órgãos públicos e das escolas para que participassem da comemoração.

Com vários dias de antecedência, os jornais do Rio de Janeiro noticiavam a organização da festa, publicavam as manifestações de adesão vindas de vários estados do País e ajudavam na convocação da população. Em longas matérias, já eram dados os detalhes da procissão cívica, quem participaria, que papel caberia a cada um dos grupos e pessoas. O cortejo compunha-se das bandas de música militares e de escolas; de grupos que conduziriam as bandeiras nacional e da Inconfidência; de delegações das escolas públicas, das associações de classe e profissionais, clubes cívicos e associações operárias; de delegações dos estados com suas respectivas bandeiras; e, em destaque, conduzidos por respeitáveis cidadãos republicanos, os bustos de Tiradentes, José Bonifácio, Benjamin Constant, Deodoro da Fonseca e Floriano Peixoto. Getúlio Vargas fecharia a procissão, participando da colocação da pedra fundamental do Templo Cívico (Jornal do Brasil, 1932a, 1932b).

Todo esse ritual já vinha sendo executado desde o final do século XIX, e fora a modalidade de comemoração da Inconfidência Mineira predominante durante a República Velha. Os republicanos haviam sacralizado Tiradentes e sacralizaram também a comemoração de sua morte. O "préstito cívico" nada mais era que uma procissão cercada de elementos do sagrado. Ele era a narrativa do evento comemorado, utilizando a linguagem religiosa como expressão. Nascida numa época em que ainda se sentia a herança do entrelaçamento institucional e cultural entre o político e o religioso, a comemoração do 21 de abril incorporou elementos dessa herança e procurava transmitir sua mensagem usando a linguagem religiosa. Não nos esqueçamos da aderência dessas refe- 
rências culturais que, remontando aos tempos coloniais, estavam fortemente impregnadas no sistema de valores da população.

O ritual manteve-se após 1930, embora se notasse o esforço do Estado para empalidecer o religioso em benefício do nacional. Não parece que tenha sido completamente bem sucedido, pois essa linguagem será retomada nas décadas seguintes, atestando sua eficácia pelo reconhecimento em sua recepção pela população. Ademais, o regime varguista tinha na valorização das tradições nacionais um dos esteios de sua propaganda, e certamente

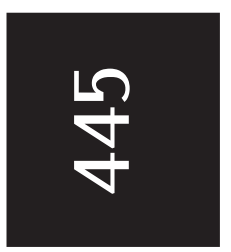
não seria boa estratégia eliminar por completo os vínculos religiosos presentes na festa cívica, ao menos nesta, que celebrava um martírio. O discurso sobre a comemoração também era pontuado pelo léxico religioso e não apenas como decorrência das representações construídas pelos republicanos. Verónica Zárate analisou situações semelhantes nas festas cívicas mexicanas do século XIX, e afirmou que o discurso político aproveitou-se das práticas exitosas da Igreja, profundamente arraigadas na cultura ibérica. Foi, então, paulatinamente se "transformando en oración patriótica y en discurso cívico.” (Toscano, 2001).

Como era comum na imprensa da época, ao noticiar as comemorações cívicas de maior vulto, agigantava-se o evento pela exacerbada adjetivação da narrativa. As fotos publicadas nos jornais demonstravam, de fato, um considerável afluxo de público, mas é importante considerar o tom laudatório dos textos. Além de ser um recurso comum nos jornais, aparecia também nos discursos pronunciados por políticos e convidados presentes nas festas e, mais permanentemente, nos textos dos livros didáticos de História ou de educação cívica utilizados nas escolas. Além da exaltação, as comparações entre o passado e o presente já iam mostrando sua utilidade e eficácia na legitimação dos grupos que tinham assumido o poder e que, pouco a pouco, passariam a comandar diretamente a organização e execução das festas cívicas no país: 
A comemoração do 21 de abril: o cenário do jogo político (1930-1960)

As excepcionais homenagens prestadas ontem à memória do valoroso chefe da Inconfidência Mineira, tiveram extraordinário brilho. O seu martírio glorioso foi relembrado contrastando as cenas trágicas do dia de sua execução, com os hinos e as explosões de civismo com que a imensa multidão que tomou parte nas comemorações timbrara em exaltar a gigantesca obra, iniciada com o suplício do destemeroso patriota.

Ouvia-se, como ouviram os nossos antepassados, o patear cadenciado dos cavalos, as baionetas, também como há cento e quarenta anos, brilharam ao sol, mas, os papéis inverteram-se. Outrora, os soldados da tirania lusitana cumpriam ordens de uma rainha cruel, ontem, eram os soldados da liberdade que davam guarda de honra àquele simples alferes de cavalaria da Milícia de Minas que tivera a coragem de afirmar bem alto, frente à frente, do poder da metrópole, que a pátria brasileira não devia carregar mais os grilhões de escrava. (Jornal do Brasil, 1932b, p.10).

O entusiasmo pela pompa da festa estimulava algumas imaginações a proporem acréscimos à comemoração, como a de que se organizasse anualmente uma romaria cívica a Ouro Preto, para que lá fossem prestadas as homenagens a Tiradentes. O autor dessa idéia estava, na verdade, antecipando Juscelino Kubitschek, que daí a vinte anos faria exatamente isso. Mas essa primeira proposta estava, na verdade, assentada sobre uma insatisfação com o governo provisório comandado por Getúlio Vargas que, ao suprimir o feriado de 21 de abril, estaria esvaziando o prestígio político de Minas Gerais. Melhor fariam os mineiros, peregrinando até Ouro Preto e conservando o culto a Tiradentes "com o mesmo entusiasmo de sempre ou, talvez, com mais ardor." (Azeredo Netto, 1932, p.13). Essa insatisfação expressava uma reação contra o processo de centralização em curso, que incluía o enfraquecimento de manifestações regionalistas em prol do nacional.

Se, no Rio de Janeiro, ainda se conservou a comemoração como uma grande procissão cívica, uma herança da Velha Repú-

Anos 90, Porto Alegre, v. 12, n. 21/22, p.437-486, jan./dez. 2005 
blica agora moldada pelo novo regime, em outras cidades, inclusive em Belo Horizonte e em Ouro Preto, as celebrações eram bem mais modestas, contando com a participação sempre mais visível da Força Pública e das escolas, em acanhados desfiles pelo centro das cidades. De certa forma isso pode ser entendido como um indício do esvaziamento das manifestações regionalistas, em prol da unidade nacional. No momento da instalação do Estado Novo, o projeto educativo e cultural se consolidou e as comemorações fora da capital federal foram reavivadas, porém de acordo com a

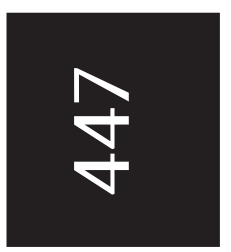
homogeneidade pretendida pelo regime.

Nos primeiros meses de 1937 as mudanças que já se operavam no cenário político se faziam sentir na vida cotidiana do País, com a vigência do estado de guerra e a tensão crescente. As manifestações públicas estavam proibidas ou restringidas, e a comemoração do dia de Tiradentes não escapou a esse estado de coisas. Os espaços abertos foram interditados, e a celebração de 21 de abril só seria permitida quando ocorresse em recintos fechados, previamente autorizada. Houve repressão e prisões onde se planejavam ajuntamentos e comícios, como ocorreu em São Paulo, na Praça da Sé. No Rio de Janeiro não aconteceu o tradicional cortejo cívico, e no local onde se realizavam as comemorações, em frente ao Palácio Tiradentes, nenhuma manifestação pública. Apenas a ornamentação colocada na estátua do herói; sequer a bandeira nacional fora hasteada.

As tensões daquele momento resvalaram ainda para um importante evento que era parte do projeto varguista de valorização da memória nacional: os atritos e diferenças políticas entre Augusto de Lima Júnior, Plínio Salgado e Benedito Valadares acabaram adiando a transferência das cinzas dos inconfidentes, do Rio de Janeiro para Ouro Preto. Os despojos haviam chegado ao Brasil em 1936 e aguardavam a viagem. O governador de Minas Gerais não aceitara o convite feito ao líder integralista por Augusto de Lima, e comunicou ao ministro Gustavo Capanema o cancelamento 
A comemoração do 21 de abril: o cenário do jogo político (1930-1960)

da participação do governo mineiro na solenidade. Além desses problemas, o acirramento do estado de tensão e o golpe de estado fizeram com que essa cerimônia, marcada para 21 de abril de 1937, só ocorresse mais de um ano depois (Estado de Minas, 1937a, 1937b, 1937c).

Apesar das restrições, o feriado nacional foi restabelecido em 1933, e as energias do governo dividiram-se entre reprimir os atos públicos que pudessem representar algum perigo e incentivar a comemoração em outras instâncias, obviamente sob o seu controle. A celebração do dia de Tiradentes em 1937 já demonstrava o teor das estratégias que seriam maciçamente empregadas durante o Estado Novo, na realização de seu projeto de uma educação cívica para a formação de uma identidade nacional coletiva. $\mathrm{Na}$ verdade, em suas características essenciais, nas atividades mais tradicionais, a festa não apresentou alterações muito profundas. Aos poucos ela era adaptada ao padrão estadonovista, marcado por um maior rigor na organização e pela homogeneidade da realização, além de ter sido expandida geograficamente.

Se já era praxe a condução, nos cortejos cívicos, de imagens de Tiradentes, geralmente na forma de bustos esculpidos, durante o governo Vargas o retrato do herói foi amplamente reproduzido e difundido. A tradição de uma política personalista no Brasil daria grande importância à imagem de Tiradentes, apresentada tanto em esculturas quanto em pinturas, levando-a ao maior número de lugares possível. Mesmo que a imagem de Getúlio Vargas devesse predominar sobre qualquer outra, essa concepção, tanto de história quanto do fazer político, punha em evidência as individualidades como motores do processo histórico. Neste sentido, em Minas Gerais o governador Benedito Valadares assinou, em 21 de abril de 1937, decreto que determinava a inauguração do retrato de Tiradentes em todos os quartéis da Força Pública do Estado e que fossem realizadas sessões cívicas em todos os grupos escolares de Minas. Essa imposição acabou tornando-se praxe, tendo sido 
mantida mesmo após o Estado Novo. O retrato de Tiradentes acabaria tornando-se elemento obrigatório na decoração dos quartéis e das salas de aula mineiras, até a década de 60. Em verdade, o universo escolar já aparecia, no início de 1937, como o espaço privilegiado para a prática do civismo. Conectando a escola e os meios de comunicação, o Ministério da Educação deixava clara a amplitude de suas ações e qual seria o seu direcionamento. No momento em que o estado de guerra esvaziava as ruas, nada mais apropriado do que internar a celebração do dia de Tiradentes: as

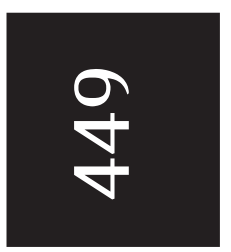
transmissões de rádio se encarregariam de levar a comemoração para dentro de casa e das escolas, por meio de palestras e discursos sobre o tema, declamações de poemas e execução de hinos patrióticos. Contidos, os jornais não demonstraram muito entusiasmo na divulgação da efeméride, economizando adjetivos e brindando os leitores com relatos lacônicos. O Jornal do Brasil, depois de historiar rapidamente a Inconfidência Mineira, concluiu sobre a importância do movimento e de sua comemoração, deixandonos um miúdo comentário, revelador do caráter da celebração naquelas vésperas do golpe de estado:

As personalidades dos intrépidos sonhadores de 1789 ficaram eternas em nossa veneração. São, hoje, como símbolos augustos da grandeza da alma do nosso povo. É, portanto, com o maior e mais justificado júbilo que a nacionalidade brasileira vê transcorrer o dia de hoje - o dia em que comemoramos os mártires da Inconfidência Mineira - estes varões que estão entre os mais puros e os mais altos idealistas que ainda viveram em terras americanas. (Jornal do Brasil, 1937, grifo meu).

Durante o Estado Novo, a comemoração do 21 de abril expandiu-se e diversificou-se quanto às atividades incorporadas à celebração. Tornou-se, no entanto, monolítica, repetindo-se todos os anos, em praticamente todos os lugares, segundo a mesma 
A comemoração do 21 de abril: o cenário do jogo político (1930-1960)

estrutura. A espontaneidade que ainda podia ser vista nas festas dos períodos anteriores, organizadas por obra e graça de associações e de entidades da sociedade civil, com modesta intervenção do Estado, quase desapareceu. Em seu lugar, a comemoração comandada, decretada, induzida, que, se não obedecia a um ritual fixo e preestabelecido - como veremos a partir do governo JK -, seguia claramente a princípios normativos de cunho ideológico e político, embora trabalhasse com a estrutura das programações antigas. Sua função primordial era a de formar a consciência cívica do cidadão trabalhador, moldá-lo de modo a transformá-lo em uma barreira eficaz às ameaças ao regime, tanto internas quanto externas.

Essa homogeneidade observada entre 1937 e 1945 era também resultante da concepção de uma nação una e coesa, que deveria reconhecer de maneira unânime uma só história, compartilhar uma mesma memória, cultuar os mesmos heróis. Conforme já foi comentado, o Estado Novo definiu a comemoração aos grandes vultos da nação como um dos principais sustentáculos de sua política cultural e educacional e, em função disso, o Ministério da Educação assumiu a gestão do calendário cívico.

A imposição dos filtros da censura refletiu-se, evidentemente, na forma como os jornais passaram a abordar a comemoração, não apenas como notícia, mas como evento político significativo. Como era de se esperar, não se ouviam as vozes dissonantes, e os jornais limitavam-se, quase sempre, à descrição das festas nos locais onde elas aconteciam. Esse caráter meramente descritivo aparecia com freqüência nos próprios títulos das matérias, que anunciavam "Como foi cultuada nesta capital a memória de Tiradentes", "O dia de Tiradentes na capital", "As comemorações da data de ontem no Rio", e assim por diante.

Dessa forma, o espaço para a manifestação dos arroubos cívicos dos cultores de Tiradentes regrediu sensivelmente e os textos laudatórios, mais profusos até o início da década de 30,

Anos 90, Porto Alegre, v. 12, n. 21/22, p.437-486, jan./dez. 2005 
ficaram cada vez mais raros. O Estado Novo, um regime que enfatizava o culto personalista do líder da nação - Getúlio Vargas - não daria, certamente, espaço excessivo para outra personalidade, talvez tão carismática e poderosa quanto à do ditador, a não ser que pudesse ser a ele relacionada e mostrada como uma parte na cadeia da formação nacional. Além disso, deveria haver controle sobre uma conotação fortemente regional, de exaltação a Minas Gerais, muito comum nesse tipo de texto, o que não se coadunava com os ditames centralistas e unitaristas do regime.

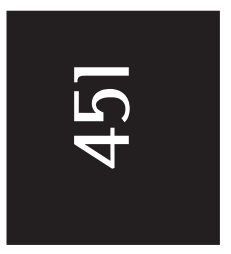
Mesmo em sua sequidão descritiva, as matérias de jornal deixavam entrever os princípios sobre os quais se assentava o Estado Novo:

As comemorações do dia 21 de abril, data em que o Brasil relembra a Inconfidência Mineira e a figura impressionante do proto-mártir Tiradentes, o santo da nossa independência, serão assinaladas em todo o território nacional com grande brilhantismo. A nação cada vez mais integrada na sua personalidade política, reverenciará a memória daquele que se sacrificou pelo ideal de sua emancipação, promovendo o movimento que está na nossa história como um marco decisivo de heroísmo e sadio patriotismo dos nossos antepassados. (Estado de Minas, 1941, grifos meus).

A idéia da unidade era ainda reforçada pela estratégia de se noticiar, detalhadamente, como as comemorações aconteciam em todo o país, indicando as cidades, os estados, as autoridades e instituições presentes, as homenagens prestadas. A imagem construída era a da nação unida na celebração do herói. A idéia da totalidade aparecia, assim, quando a comemoração tinha acontecido em "todo o país", em "todo o estado", em "toda a cidade", em "todos os centros de cultura", em "todos os grupos escolares", em "todas as escolas secundárias", em "todos os quartéis da Força Pública", em "todos os centros cívicos", em "todas as associações 
A comemoração do 21 de abril: o cenário do jogo político (1930-1960)

de classe". Quando não se podia falar no todo, falava-se nas quantidades, em "numerosos", na "maioria", etc. Os textos laudatórios tradicionais, com menor espaço nos jornais durante este período, não deixaram, contudo, de aparecer, mas louvando também o Estado Novo e Getúlio Vargas, ao lembrar os mártires do século XVIII:

\begin{abstract}
Os tempos, porém, passaram, e o Brasil, sob a alvorada da Democracia e da República, tem sabido consagrar à memória do Mártir e dos seus companheiros, mais crescendo ano a ano, o entusiasmo cívico das comemorações. O Brasil Novo, rejuvenescido pela integração em si mesmo, uno, forte, redivivo em todas as suas energias vitais, sob a chefia unida de seu grande vanguardeiro, Presidente Vargas, mais do que nunca tem dado à Glória dos inconfidentes a sagração histórica merecida. (Estado de Minas, 1942b).
\end{abstract}

A idéia do uno aparecia, ainda, no destaque àqueles setores da sociedade brasileira a quem fora atribuído, pelo Estado Novo, papel relevante na construção e consolidação da nação: as escolas, as associações de trabalhadores e as instituições militares. Estes grupos apareciam como os principais protagonistas das celebrações, feitas por eles e para eles. A pretensão da unidade também se expressava na uniformidade dos programas celebrantes, quase os mesmos em todos os lugares e, em geral, obedecendo a mesma seqüência: hasteamento da bandeira, execução do Hino à Bandeira e do Hino Nacional, palestras para estudantes e trabalhadores, apresentação de trabalhos escolares sobre Tiradentes, declamação de poesias alusivas à Inconfidência Mineira e aos seus principais personagens, apresentação de poemas e peças sobre temas patrióticos, leitura da biografia de Tiradentes, dramatizações da Inconfidência Mineira, competições esportivas. Nos artigos ou nas transcrições de discursos, publicados nos jornais da época, ressalta a preocupação em chamar a atenção para a herança de Tiradentes,

Anos 90, Porto Alegre, v. 12, n. 21/22, p.437-486, jan./dez. 2005 
para os frutos de seu sacrifício, que teriam deixado para a nação seus pendores para a liberdade e para a defesa da soberania, fazendo do Brasil um país "livre das peias e intromissões adventícias, graças, inclusivamente, ao exorcismo cívico ditado pelo nosso sentimento de brasilidade." (Estado de Minas, 1938).

A ênfase no perigo das "intromissões adventícias" era comum desde meados da década de 30, tendo-se acentuado após o movimento comunista de 1935. Mesmo depois de instalado o Estado Novo, o discurso político não abandonava essas referências,

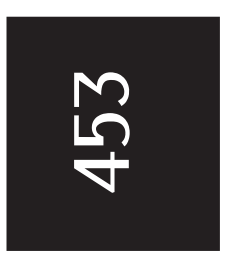
reforçando no imaginário a existência de um perigo permanente, que continuava a justificar o controle sobre a sociedade. Assim, não foi incomum que o heroísmo de Tiradentes fosse lembrado como exemplo para as lutas contra aquelas ameaças. Na comemoração de 1939, o General Meira de Vasconcelos, comandante da $1^{2}$ Região Militar, fazia um pronunciamento bastante elucidativo a respeito, divulgado no Boletim Regional da corporação e publicado pelo Jornal do Brasil (1939):

A comemoração do feito de Tiradentes é, pois, uma exaltação de que nos devemos orgulhar, honrá-la e glorificála, pela significação moral que marcha, se avoluma e se eleva com os tempos. Ela é o protesto contra o domínio, contra a extorsão, assédio econômico, e nos tempos que vivemos, vendo flutuar o pavilhão das cores deslumbrantes da jornada de 1822, assistimos a renovação multiforme desse cerco, a ameaça de povos contra nós, a política de infiltração perigosa que encontra a seu favor uma coletividade de educação falha de civismo, displicente, vivendo apenas a existência regional e perigosa pela incompreensão dos deveres que enfeixam problemas nacionais. [...] A época traz para nós acréscimos de deveres, eles se multiplicam, exigem que ingressemos toda a nação na política de segurança, educando-a em rumos que permitam à coletividade brasileira se alistar para a batalha dos tempos atuais, onde nenhum deve faltar, para que o patrimônio secular não faça 
A comemoração do 21 de abril: o cenário do jogo político (1930-1960)

parte da repartição que a truculência internacional premedita, já com pontos de apoio no Continente e pense assim dispor de nossa soberania.[...] Cumpramos o nosso dever prosseguindo a velha e tradicional política do Brasil, dentro do espírito de harmonia, mas conscientes de que podemos impor, mesmo pela força, nossa vontade contra quem quer que ameace a nossa integridade.

O general fez da exaltação a Tiradentes um pretexto para trazer aos seus comandados e, por extensão, aos leitores do jornal, o cenário soturno daquele final de década, marcado ainda pela ameaça comunista e pelas sombras da guerra que pairavam sobre a Europa. Justificava, ainda, o uso da força no esforço de contenção das ameaças, internas ou externas. A conclamação do povo ao patriotismo e à defesa nacional, a exemplo do que fizera Tiradentes no século XVIII, já anunciava o discurso que se faria depois da entrada do Brasil na Segunda Guerra Mundial. O sacrifício de Tiradentes deveria ser seguido por seus compatriotas, instados a participarem da luta contra o fascismo na Europa.

No início de 1942, já rompidas as relações diplomáticas do Brasil com os países do Eixo, aumentava cada vez mais a perspectiva da entrada do País na guerra. É sobejamente conhecido o clima de tensão e expectativa, o crescimento das manifestações de repúdio ao fascismo e as pressões de alguns setores da sociedade para que o Brasil tomasse uma posição mais definida no conflito. Nas comemorações de 21 de abril de 1942, antes mesmo da declaração formal de guerra, que ocorreria em agosto daquele ano, Tiradentes já servia como o exemplo do sacrifício que talvez tivessem que fazer muitos jovens brasileiros. Numa sessão cívica realizada no Cine Brasil, em Belo Horizonte, à qual compareceram representantes "de todas as classes sociais da cidade, escolares, militares, operários, estudantes dos cursos secundários e superiores, além das autoridades civis e militares", ficou registrado o apelo ao sacrifício da juventude, no discurso do representante dos 
diretores de escolas secundárias da cidade. Depois de uma preleção sobre o martírio de Tiradentes, o diretor o apontou, segundo o jornal, como "exemplo à juventude, de quem a pátria agora, mais do que nunca, irá necessitar. Sua oração [do diretor] foi uma conclamação à mocidade, para que num juramento solene, assumisse o compromisso ineludível [sic] de ir ao sacrifício - se precisar - para defesa de nossa civilização e liberdade." No encerramento da sessão foi criado o Centro do Culto Cívico da Juventude Brasileira, com sede na escola dirigida pelo mesmo orador, "com o fim de homenagear os grandes vultos brasileiros." (Estado de Minas, 1942a). Vê-se como a idéia do sacrifício, presente nas representações de Tiradentes, podia migrar de sua dimensão puramente religiosa para a dimensão patriótica, numa fusão de sentidos que, mais uma vez, encontrava eco na formação cultural brasileira.

Até a definição da posição do Brasil no conflito mundial, os discursos enaltecedores publicados nos jornais, colocavam a questão da liberdade em sua dimensão mais econômica, numa exortação à defesa das pretensões de autonomia do país nesse campo. Ou então o tema aparecia um tanto burocraticamente, apenas como uma menção obrigatória, quase vazia de sentido. A exaltação da liberdade e da democracia não encontrava respaldo na realidade política do país, a não ser que fosse compreendida em outro registro, aceito pelo regime. Essas duas idéias poderiam, desta forma, referir-se mais estritamente ao rompimento das ingerências externas, no campo econômico, por exemplo, e das ameaças de uma escravização do povo brasileiro, que seria decorrente de uma adesão ao comunismo.

Após a declaração de guerra, contudo, não apenas a palavra liberdade, mas também a democracia, começaram a aparecer de forma mais contundente, trazendo seus significados cada vez mais bem delineados em referência ao cenário político, tanto o externo quanto, e principalmente, o interno. Essas duas palavras e seus sentidos foram sendo utilizados cada vez mais como a denúncia 
A comemoração do 21 de abril: o cenário do jogo político (1930-1960)

de sua inexistência no Brasil daquele momento, e como ideais a serem ainda conquistados. Mais uma vez a Inconfidência Mineira mostraria sua operacionalidade como instrumento de legitimação de posições políticas, ao ser evocada como bandeira da redemocratização.

Noticiando a preparação das comemorações do bicentenário de nascimento de Tomaz Antônio Gonzaga, um jornalista deixou escapulir, ao referir-se à idéia de democracia, uma caracterização das vivências políticas no Brasil daquela época, remetidas ao tempo da Inconfidência Mineira. Segundo ele,

[...] todos estão conscientes da necessidade de participarem ativamente nesse movimento que visa a homenagear a memória de um dos inconfidentes de primeiro plano, precursores das aspirações republicanas do Brasil, que se sacrificaram pela democracia que não chegaram a conhecer, mas que havia de florescer irresistivelmente no coração de todos os brasileiros, como norma ideal de vida e de compreensão humana. (Estado de Minas, 1943a, grifo meu).

O tom das referências foi ficando cada vez mais claro à medida que as manifestações de oposição ao Estado Novo ficavam mais nítidas, e de 1943 a 1945 os jornais foram paulatinamente abordando o tema de forma mais direta. Naquele momento a construção de analogias entre a luta de Tiradentes e dos brasileiros do presente passava a fazer mais sentido, e a idéia de liberdade ganhava mais substância, num contexto em que ela era uma reivindicação presente e concreta. A explicitação dessas associações pôde ser lida na mensagem ao povo mineiro, feita pela Sociedade dos Amigos da América, por ocasião da comemoração de 21 de abril de 1943. Nela, depois de exaltar a importância dos heróis para a formação das nações, o autor lembrava que 
Tiradentes, esse visionário da libertação e da emancipação política do Brasil, é bem um símbolo das nossas mais puras aspirações de grandeza nacional, de democracia e liberdade. [...] Esse minuto de silêncio e de vigília cívica que hoje nos congrega e nos irmana, assume, precisamente nessa data, uma significação mais ampla e mais profunda. Estamos empenhados numa guerra contra as forças liberticidas do mundo, contra o fascismo, o nazismo e todas as modalidades de escravização do homem. Estamos lutando contra a força bruta, a estatolatria e a quinta coluna, batalhando pela permanência e pela restauração da dignidade humana e da democracia no mundo de nossos dias. [...] Contemplando o heroísmo sublime do Alferes e a serenidade imperecível de seu heroísmo, todos os mineiros poderão hoje fazer um voto de fé na justiça humana, na democracia e na liberdade. (Estado de Minas, 1943b).

Em abril de 1945, as comemorações do dia de Tiradentes foram escolhidas como o momento ideal para uma grande manifestação de oposição ao governo Vargas e de campanha pelo retorno da ordem democrática. Nos primeiros meses daquele ano já se organizavam os novos partidos políticos que dominariam o cenário brasileiro até os meados dos anos 60 (UDN, PSD e PTB), e se discutia a realização de eleições. Nessa altura estava sendo articulada, pelo PRM e pela UDN em Minas, a candidatura do brigadeiro Eduardo Gomes para a presidência da República. Tiradentes seria, mais uma vez, levado como bandeira legitimadora das práticas políticas, demonstrando toda a sua maleabilidade. As justificativas para a escolha do dia da celebração de sua morte como momento de luta pela democracia davam um caráter bem mais acentuado à idéia de liberdade, identificada com democracia, e elevando o seu sentido pela dupla natureza da luta, ou seja, contra o despotismo externo, vencido na guerra na Europa, e contra o despotismo interno, vencendo-o na derrubada no Estado Novo:

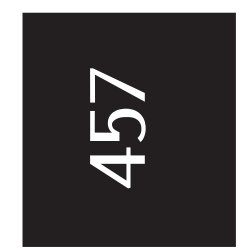


A comemoração do 21 de abril: o cenário do jogo político (1930-1960)

As oposições coligadas de Minas farão realizar no próximo sábado, 21, um grandioso "meeting”, com a participação de elementos de todas as correntes da capital. O comício [...] é um justo preito ao grande vulto da independência brasileira, símbolo das lutas pela Liberdade, mártir da boa causa. Mesmo nos anos mais negros do fascismo nacional, não se esqueceram os democratas de Minas da figura ímpar do líder da conjuração mineira e, agora, novamente se lembram de Tiradentes, guia inolvidável dos que se empenham por uma Pátria livre. O "meeting" será, pois, de homenagem a Joaquim José da Silva Xavier, nesta hora em que toda Minas e todo o Brasil se levantam para quebrar os grilhões impostos pelo golpe de Estado de 1937. (Estado de Minas, 1945a, grifo meu).

O jornal conclamava a população à participação no comício, organizado pelo Comitê Central Pró-Eduardo Gomes, de Belo Horizonte, elencando os pontos principais das reivindicações da oposição: a anistia, o reconhecimento da URSS, o fim do Departamento de Imprensa e Propaganda e do Tribunal de Segurança e a revogação da Constituição de 1937. Em cada um deles a idéia de liberdade adquiria especial significado, facilitando sua identificação com as representações da Inconfidência Mineira e da ação de Tiradentes, o que faziam os jornais, cada vez menos tolhidos pela ação da censura. No dia do grande comício organizado pela oposição, um editorial esclarecia, sem constrangimentos, essa desejada conexão entre o passado e o presente:

A comemoração da data de hoje, que recorda o sacrifício de Tiradentes, herói e mártir da Inconfidência Mineira, reveste-se este ano de singular expressão. Nunca o Brasil esteve mais identificado do que agora com o ideal libertário e com aquelas reivindicações de justiça que inflamaram a consciência dos rebelionários [sic] de Vila Rica. Hoje, como naqueles dias agitados e confusos da nossa história, a paixão da liberdade é a poderosa força íntima a que se rendem todos os homens ainda não escravizados. É a continuação 
da mesma luta contra a violência do poder, da mesma revolta contra o primarismo dos regimes de arbitrio e opressão. (Estado de Minas, 1945b, grifo meu).

A maleabilidade do mito está vinculada, na verdade, às múltiplas possibilidades de sua apropriação pelo discurso político quando as idéias que ele representa permitem adaptações circunstanciais. Tiradentes é um desses casos, como símbolo da luta pela liberdade. Durante o Estado Novo, a liberdade foi usada como

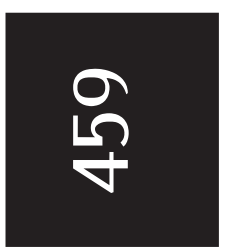
significando a libertação dos grilhões da pobreza, da ignorância e do atraso econômico; a libertação da opressão causada pela falta de amparo aos trabalhadores; a libertação das dissensões internas e da falta de civismo. Durante a crise que levou ao golpe de 1937, a luta pela liberdade significava barrar o avanço das forças dissolventes da nação brasileira, ou seja, o comunismo. Depois, com a guerra, a liberdade tornou-se bandeira também em outra frente, contra o fascismo. Nesses momentos, foi possível para os grupos políticos no poder apropriarem-se de Tiradentes como exemplo de luta e símbolo de uma idéia. No ocaso do regime, novamente ele aparecia, sem constrangimentos, agora em defesa da liberdade e da democracia, pelo fim da ditadura e do "fascismo nacional".

As mudanças políticas que culminaram com o final do Estado Novo arrefeceram o ímpeto da festa cívica de 21 de abril, após a ebulição dos movimentos pela redemocratização do país, em 1945. Até o início da década de 50, a celebração continuou concentrada nas escolas e nos quartéis, e a imprensa foi pouco pródiga na destinação de espaço para Tiradentes e sua heróica jornada. Esse ligeiro esvaziamento foi sentido por muitos e desencadeou algumas reações, parte delas com forte acento regionalista, expressando a necessidade da recuperação do brilho das homenagens ao mártir da independência nacional. Embora as manchetes dos jornais continuassem a pintar um cenário grandioso para as comemorações, as matérias em si não empolgavam. Os jornais falavam 
A comemoração do 21 de abril: o cenário do jogo político (1930-1960)

sobre o interesse pela comemoração da efeméride, sensivelmente reduzido; sobre os poucos vereadores nas sessões solenes da Câmara Municipal de Belo Horizonte; sobre a omissão da Secretaria de Educação, que não mais recomendava às escolas a realização de comemorações; sobre a celebração no Rio de Janeiro que, se continuava a acontecer, era graças à ação do Centro Mineiro e de seus associados. ${ }^{3}$ Muitos jornalistas, em seus editoriais, chegavam a atribuir esse "descaso" à supressão do feriado de 21 de abril, em 1949, o que teria colocado a comemoração em segundo plano. Para eles, o seu retorno seria condição para novamente elevar a data à sua posição privilegiada.

A situação se alteraria sensivelmente a partir de 1952, quando Juscelino Kubitschek, então governador de Minas Gerais, decidiu transformar o 21 de abril em importante instrumento de propaganda. Hábil no manejo de símbolos e de imagens, Kubitschek dispensou especial atenção às comemorações do dia de Tiradentes, transformando-as em cenário para a legitimação de seu governo e de seus aliados, ao mesmo tempo em que procurava dar a elas projeção nacional. ${ }^{4}$ Naquele ano, durante todo o mês de abril, a imprensa abriu espaço generosamente para as notícias sobre a preparação da festa. Criava-se um clima de expectativa em torno da celebração, apontada como a revitalização do culto a Tiradentes como modelo cívico brasileiro. Não escapava à imprensa a dimensão regionalista assumida pela comemoração, e isso ajudava a dar maior visibilidade ao projeto de governo de Kubitschek, sobretudo em sua vertente modernizadora. A imagem de um governo que promovia o progresso do estado ao mesmo tempo em que valorizava as tradições e o passado de Minas Gerais era um poderoso instrumento de propaganda, utilizado com eficácia pelo governador.

Todos os elementos simbólicos possíveis foram explorados na organização da festa. Em primeiro lugar, ficava ressaltada a importância da realização das comemorações oficiais "no cenário 
da Inconfidência Mineira, na cidade de Ouro Preto." (Estado de Minas, 1952a). Até então, essa comemoração acontecia na capital do estado, Belo Horizonte, e as manifestações em Ouro Preto, embora ocorressem, não tinham muita expressão. A estratégia de Kubitschek era poderosa: transferir para esta cidade, naquele dia significativo, a sede do governo mineiro. Com esse ato promoviase uma volta ao passado, relembrando os tempos da Vila Rica, capital da Capitania das Minas Gerais, os mesmos tempos da conspiração agora comemorada.

A realização da festa na praça central da cidade relembrava, também, os tempos da opressão da coroa portuguesa, quando nesse local ficara exposta a cabeça decepada do alferes conspirador, e onde fora pronunciado, em maio de 1792, o discurso de júbilo pela derrota da conspiração, proferido por Diogo Pereira Ribeiro de Vasconcelos. O amedrontado vereador do Senado da Câmara de Vila Rica errara cabalmente sua previsão quando, apontando para a cabeça de Tiradentes, exposta na praça, exortara o povo a que deixasse "esse desgraçado servir ao exemplo da futura idade, que dele se não lembrará sem formar a idéia da sua ingratidão, de seu opróbrio e suplício." (Autos..., 1977, p.138). De fato, Vasconcelos acertara apenas quanto ao último ponto. O suplício de Tiradentes seria uma das motivações de sua lembrança. Cento e sessenta anos depois, no mesmo lugar, a celebração da memória de Tiradentes tinha sabor de desagravo, e os que a promoviam a usariam para a autopromoção. Além disso, o retorno a Ouro Preto, uma espécie de "volta às origens", daria à comemoração contornos de uma liturgia a ser realizada em campo santo, por meio da romaria cívica que se faria para a veneração do herói-mártir. ${ }^{5}$ Aqui desponta, novamente, a força das referências religiosas na construção, circulação e recepção das representações em foco.

A preocupação com a repercussão política da festa orientou a instalação do governo em Ouro Preto - para onde iriam, além do governador, todos os secretários, autoridades civis e militares e

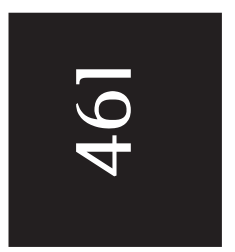


A comemoração do 21 de abril: o cenário do jogo político (1930-1960)

parlamentares - e a elaboração da lista de convidados, que incluía ministros de Estado, membros do Supremo Tribunal Federal, da Academia Brasileira de Letras, dos Institutos Históricos Brasileiro e de Minas Gerais, jornalistas e educadores. Se o comparecimento não foi total, isso não parece ter diminuído o impacto da comemoração, que acabou adquirindo um novo estilo. Uma tradição estava sendo construída nesse momento, com um ritual especialmente preparado, retomando parcialmente algumas características das festas cívicas já consolidadas e incorporando novas, que se firmaram e são até hoje mantidas.

O governo do estado deu encargos especiais à Secretaria de Educação para a elaboração da programação da festa, não apenas no âmbito escolar, mas em todos os seus aspectos. O programa, à medida que se definia, era divulgado pela imprensa, o que ajudava a criar o clima de expectativa desejado pelo governo. Em todos os editoriais e reportagens que antecederam a comemoração, o destaque recaía sobre a volta de Ouro Preto à sua condição de capital, e cercavam-se de imagens que procuravam impressionar os leitores. Imponência, grandiosidade, brilhantismo, pompa, esplendor, beleza, entusiasmo, eram os substantivos mais utilizados pelos jornais ao se referirem à comemoração. Deve-se considerar que tanto o Estado de Minas quanto o Diário de Minas apresentavam um razoável grau de comprometimento e demonstravam seu apoio à política de desenvolvimento de Kubitschek, mesmo o Estado de Minas, que tinha em seus quadros muitos simpatizantes da UDN (cf. Simões, 2000).

A representação de Tiradentes, apropriada nessa comemoração de 1952, foi a do herói cívico, do ativista político, o que não significa que alguns dos elementos do mártir cristão não se deixassem aflorar. A começar pela sacralização do espaço de celebração, atestado pela volta de Ouro Preto como capital de Minas, e pela revalorização da Praça Tiradentes como local privilegiado do culto cívico. A imagem de uma peregrinação era reforçada pelos tex-

Anos 90, Porto Alegre, v. 12, n. 21/22, p.437-486, jan./dez. 2005 
Thais Nivia de Lima e Fonseca

tos jornalísticos e pelo discurso político, e aos participantes da celebração era sugerida a condição de romeiros.

Outro dado importante nas considerações sobre a organização dessa festa pelo governo Kubitschek foi a ênfase dada, então, à idéia de unidade, de consenso em torno da celebração. Marco ideológico do Estado Novo, essa idéia mostrou sua eficácia e sua durabilidade, e Juscelino Kubitschek foi hábil em sua utilização. Traço marcante da tradição política brasileira, a idéia de unidade nacional cercava-se de outras, que seriam constituintes do caráter brasileiro, como o espírito pacífico, a cordialidade, a tolerância. Essas características, ou melhor dizendo, essas representações do povo brasileiro têm sido evocadas com insistência, mesmo quando a realidade evidencia o contrário. E em momentos de afloramento de conflitos ou divergências políticas incômodas, essas representações podem se mostrar bastante úteis. Por isso a importância da iniciativa de Kubitschek na criação de uma liturgia política, como uma enunciação cerimonial de seus princípios e de seus códigos de ação (cf. Rivière, 1989, p.21).

Juscelino Kubitschek, apesar de sua grande popularidade, nunca foi uma unanimidade, ao contrário da imagem mais difundida sobre ele posteriormente. Desde os tempos de sua gestão na prefeitura de Belo Horizonte (1940-1945), seus projetos sofriam acirrada oposição, que podiam ser tanto de natureza econômica (os gastos vultosos com os grandes projetos) quanto de natureza estética (a opção pela arquitetura moderna, ainda pouco aceita pelas conservadoras elites mineiras). São bastante conhecidos os impactos provocados por várias de suas iniciativas, desde a construção do conjunto arquitetônico da Pampulha, em Belo Horizonte, até a construção de Brasília. E nos momentos em que as oposições e críticas a seus projetos tornavam-se mais estridentes, ele nunca deixou de lançar mão da idéia de unidade em torno de um ideal, chamando o povo a seu "verdadeiro" espírito, o do entendimento. Nessas ocasiões, o apelo ao passado de Minas mostrava

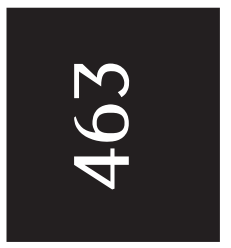


A comemoração do 21 de abril: o cenário do jogo político (1930-1960)

suas vantagens, e é nessa perspectiva que é possível entender a institucionalização da festa de 21 de abril.

A Assembléia Legislativa de Minas Gerais aderiu ao "espírito de união", e em sua sessão comemorativa do 21 de abril de 1952 ouviram-se os discursos exaltadores e convergentes dos representantes de todos os partidos políticos (Estado de Minas, 1952b, p.3). ${ }^{6}$ Foi nessa ocasião que o deputado Valdir Lisboa, do PTB, apresentou o projeto de lei instituindo a Medalha da Inconfidência, "destinada a galardoar o mérito cívico do cidadão que, em Minas, se distinga pela notoriedade de seu saber, cultura e relevantes serviços à coletividade." (Estado de Minas, 1952c, p.7). O deputado tentava a aprovação dessa proposta desde 1949 e ela foi, finalmente, concretizada no momento em que o Estado apostava muitas fichas no poder de legitimação e de reconhecimento da celebração da morte de Tiradentes. ${ }^{7}$

O ineditismo dessa comemoração foi alardeado pelos jornais, que a descreveram em detalhes, ainda por vários dias depois de sua realização, não poupando elogios e comentários exaltadores. Em seus detalhes, a comemoração preparada pelo governo Kubitschek fundava as bases do ritual que seria definitivamente incorporado ao calendário cívico. A chegada do governador e do alto escalão do governo a Ouro Preto, na estação da Central do Brasil, foi acompanhada por uma pequena multidão que seguiu a comitiva até a Praça Tiradentes. Lá, recebido pela nova guarda da Polícia Militar, que acabara de criar, Kubitschek caminhou até o palanque armado em frente ao Museu da Inconfidência, passando pelas formações de estudantes de todas as escolas de Ouro Preto, assistidos pela população que se apertava nas sacadas e janelas dos sobrados em torno da praça. O governador, solene, depositou uma coroa de flores aos pés da estátua de Tiradentes. Após um minuto de silêncio, as bandas militares executaram o Hino Nacional. Kubitschek fez, então, seu pronunciamento. 
Apesar de estar inventando uma tradição comemorativa do governo mineiro, Juscelino Kubitschek falou como se estivesse, na verdade, dando continuidade a uma tradição já antiga, apenas valorizando-a condignamente ao transferir para Ouro Preto todo o governo estadual. A festa era, para ele, atinente aos mineiros, antes de tudo; um resgate de suas mais caras tradições, respeitando seus valores. Mas representaria também as aspirações nacionais de união e de progresso, pois foi com base nesses ideais que se construíra a identidade nacional. $\mathrm{E}$ a preeminência de Minas se

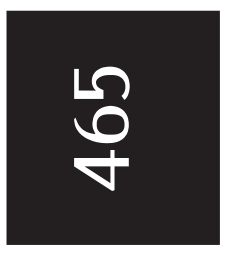
explicaria por meio da Inconfidência Mineira, pois teriam sido os inconfidentes de 1789 "a nossa primeira grande geração política autenticamente brasileira, pelas diretrizes de seu espírito, pelas raízes e relevância de sua obra e de seu exemplo, pelo alcance de seu pensamento." (Kubitschek, [s.d.], p.91). ${ }^{8}$ A comparação entre o passado e o presente dava vida à comemoração e equiparava, em importância, as elites brasileiras do período colonial e as do século XX, o que incluía o próprio Kubitschek. Assim, a comemoração ganhava

[...] a presença de personalidades que, atuando em diferentes setores e ao peso de diferentes responsabilidades, se devotam igualmente a construir a prosperidade e a grandeza do Brasil e têm como único roteiro e objetivo o bem comum, que enobrece e concretiza a felicidade da Pátria. [...] Filho de uma cidade que também ostenta o brasão de haver lutado pelas causas sagradas de nossa Terra, sinto-me hoje feliz ao transportar, por algumas horas, para a antiga e nobre Capital das Minas Gerais, o Governo com todos os seus componentes, para, numa homenagem comovida e filial render à grande, poética e encantadora célula do civismo brasileiro, que é Ouro Preto, o culto sagrado do povo mineiro, que nesta hora, pela voz de seu Governo, vem dizer aos seus filhos que, enquanto os homens tiverem memória, esta cidade e esta data viverão perenes e palpitantes na lembrança da Pátria agradecida. (Kubitschek, [s.d.], p.91, 95-96).

Anos 90, Porto Alegre, v. 12, n. 21/22, p.437-486, jan./dez. 2005 
A comemoração do 21 de abril: o cenário do jogo político (1930-1960)

Kubitschek foi, sem dúvida, sagaz ao manobrar, simbolicamente, passado e presente, e ao valorizar a identidade regional relacionada a uma identidade nacional. Coroado por seu discurso, o ritual comemorativo estava eivado de elementos simbólicos importantes como lugares de memória: o trajeto a pé até o monumento a Tiradentes, sinal de humildade e reverência ao mártir; a deposição de flores aos pés do monumento, túmulo simbólico, numa homenagem ao herói patriota; o minuto de silêncio, em honra ao sacrifício; os aviões que sobrevoaram a cidade lançando flores sobre a praça, um espetáculo do poder, unindo força e delicadeza, modernidade e tradição. O povo assistia atrás do cordão de isolamento, espremido nas estreitas calçadas da Praça Tiradentes, e não parecia ter outro papel que não fosse o de espectador. A estrutura da festa, em verdade, assentava-se em uma hierarquia que ia desde as autoridades e seus convidados ocupando o palanque oficial, passando pelos destacamentos militares, bandas de música e delegações de escolares perfilados no centro da Praça, até a população espectadora. Não bastaria ao espaço da festa ser sacralizado; ele deveria também ser disciplinado e controlado.

Daí em diante, com pequenas variações aqui e ali, a comemoração do 21 de abril seguiu esse ritual, tornando-se uma tradição que todos os governos, depois de Kubitschek, fizeram questão de manter. Mas os investimentos políticos da festa do dia de Tiradentes não se limitaram a essa cerimônia "inaugural" de 1952. Nos anos seguintes Juscelino Kubitschek continuou a explorá-la, mesmo enquanto esteve na presidência da República, entre 1956 e 1960. A idéia de uma modernização que realizava os sonhos dos inconfidentes foi diversas vezes utilizada. Em 1953, por exemplo, o governador escolheu o 21 de abril como momento para a inauguração da estrada que ligaria Belo Horizonte a Ouro Preto, batizada como Rodovia dos Inconfidentes. Kubitschek tinha no setor de transportes um dos eixos de sua plataforma, e a abertura de uma rodovia que, além da ligação entre as duas cidades, também era 
uma das etapas da construção da estrada que ligaria a capital mineira ao Rio de Janeiro, ganhava em importância ao ser inaugurada durante as comemorações do dia de Tiradentes. Em outra ocasião, já em campanha para a presidência da República, Kubitschek participaria da comemoração de 21 de abril de 1955, inaugurando um forno de ferro-liga em Saramenha, nos arredores de Ouro Preto. Mais uma vez a produção de ferro era associada aos projetos dos inconfidentes, e os governos mineiros do século XX seriam seus realizadores. Em 1956, já com JK na presidência da República,

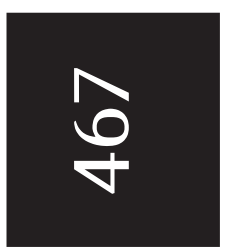
era a vez de inaugurações na Companhia Siderúrgica Mannesmann serem feitas durante as comemorações da Inconfidência Mineira.

A idéia de progresso como uma representação da Inconfidência Mineira não havia sido utilizada com tanta veemência e clareza até então. Kubitschek, que a associava à sua própria imagem, procurava no passado razões que dessem aos seus projetos uma credibilidade ainda maior, e que lhe dessem vitória no combate que travava com seus opositores. A insistência na antigüidade das propostas de progresso e de modernização de Minas Gerais e, por extensão, do Brasil, não deixava de ser um ataque a grupos políticos do presente e do passado: o que tinham feito todos os governos brasileiros, que foram incapazes de realizar os sonhos dos inconfidentes? Essa era a pergunta que JK deixava no ar, ao associar seu Binômio Energia e Transportes ao movimento setecentista mineiro.

Enquanto, em Minas Gerais, se criava uma tradição em moldes novos para essa festa, no Rio de Janeiro mantinha-se a antiga, realizando-se a cerimônia, como há muitos anos, defronte ao $\mathrm{Pa}$ lácio Tiradentes, sede da Câmara dos Deputados, com a participação de escolas e destacamentos militares que homenageavam Tiradentes com coroas de flores e desfiles diante de sua estátua. A festa parecia ir se esvaziando na capital federal, enquanto crescia na antiga capital das Minas Gerais. Juscelino Kubitschek contribuía, sem dúvida, para valorizá-la, convidando, a cada ano, 
A comemoração do 21 de abril: o cenário do jogo político (1930-1960)

personalidades de relevo nacional, como ministros de Estado, governadores e, em 1954, o próprio presidente da República.

A presença de Getúlio Vargas como principal orador da comemoração de 21 de abril de 1954 ocorreu num momento político crítico, quando o presidente já sofria revezes em seu governo, com uma crescente e articulada oposição capitaneada pela UDN. O convite a Vargas teve certo caráter de desagravo ao presidente, da parte dos partidos que o apoiavam. O governador Juscelino Kubitschek preparou uma pomposa celebração para recebê-lo, agregando novos elementos ao programa da festa, como concerto de música sacra, encontros com várias autoridades, almoço especial e espetáculo de fogos de artifício. Sete governadores de estado foram convidados, antecipando uma reunião de cúpula do PSD, já marcada para acontecer em Belo Horizonte. Os jornais, sempre afeitos à exaltação patriótica na ocasião de 21 de abril, acabaram por deixar Tiradentes em segundo plano, diante das estrelas políticas que brilharam em Ouro Preto naquele ano de 1954, e do especial significado assumido pela festa naquele momento, marcado pela transição de governo que se aproximava.

Além das articulações políticas, o tom de desagravo foi sentido no longo discurso proferido por Juscelino Kubitschek, antes de passar a palavra ao presidente Getúlio Vargas. Sua "Invocação de Tiradentes" já começava apontando quem seria, de fato, o homenageado do dia. O herói da Inconfidência Mineira era invocado, em primeiro lugar, como "a inspiração de que tanto necessitamos todos nós, nesta hora difícil que a Pátria, de que ele foi um dos fundadores, está atravessando.” (Kubitschek, [s.d.], p.399). Ao saudar Getúlio Vargas, o governador não se esqueceu de destacar as ligações pessoais e profissionais do presidente com a cidade de Ouro Preto, sua vivência lá como estudante, sua atenção para com a preservação do patrimônio histórico e cultural mineiro e brasileiro durante seu primeiro governo. Seu discurso trazia de volta as 
idéias de unidade nacional, tão caras ao Estado Novo, agora novamente importantes no momento de crise:

A oportunidade de se reunirem tantos cidadãos em cujos ombros pesam as responsabilidades de governo, a começar pelo Sr. Presidente da República, o fato de estarem voltadas para esta festa as atenções de todo o País oferecem o ensejo de se dedicar o dia de hoje à exaltação da Unidade Nacional. É isso o que desejo propor aos que me ouvem e a todos a quem alcançar a minha palavra, não importa onde e quando. O dia de Tiradentes deve ser o dia da Unidade Nacional. (Kubitschek, [s.d.], p.401-402, grifo meu).

Como ocorrera em outras ocasiões, Tiradentes era apropriado como exemplo de dedicação à pátria e como elo de união nacional. Ao mesmo tempo, o lugar de memória privilegiado, a própria cidade de Ouro Preto, era lembrada como o berço das idéias de libertação da nação, dando à celebração a dimensão de ritual sagrado. O discurso de Kubitschek apontava, nas entrelinhas, as dissensões internas e as pressões externas que ameaçavam a unidade nacional. Encerrando seu pronunciamento, o governador de Minas Gerais conclamava a nação para que, espelhando-se em Tiradentes, fizesse renascer sua fé no futuro do Brasil, fizesse a promessa de lutar "contra a desagregação, contra o divisionismo, contra a deliqüescência, contra a falta de fé que ameaça a alma brasileira." Segundo Kubitschek ([s.d.], p.410), a solução da crise estaria "em avivar na alma do povo o amor e a fé que a Nação exige para realizar a sua grande missão."

Tomando a palavra, Getúlio Vargas procurou acolhimento no ambiente que já lhe era familiar, de quando estudara na Escola de Minas, falando ao "povo de Minas" de forma sentimentalista e elogiosa. Lembrou seu governo anterior, e todas as medidas tomadas para transformar Ouro Preto em patrimônio nacional e para preservar a memória da Inconfidência Mineira. No discurso, seu

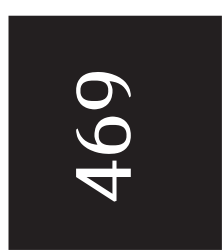


A comemoração do 21 de abril: o cenário do jogo político (1930-1960)

governo continuava no de Juscelino Kubitschek, que dava a Minas Gerais projeção nacional, não apenas por sua história, mas também pelo seu progresso. Enfim, chegado o momento de exaltar o herói celebrado, Vargas abriu-se para a exaltação de si próprio, tecendo comparações entre o sacrifício de Joaquim José da Silva Xavier e o seu. Tiradentes, que segundo Vargas lutara pela autonomia da nação, era exemplo para o presente, pois

[...] a distância do tempo não afasta a sua atualidade. É ainda a mesma bandeira que estamos empunhando na luta dos nossos dias, é a luta de um governo legitimamente constituído, de base nacionalista e popular, contra a mentalidade negativista, que descrê do nosso futuro, das nossas possibilidades e reservas da capacidade criadora de nossa gente, enfim que não acredita no Brasil. (Estado de Minas, 1954, p.7).

Chamando para si a atenção como instrumento dessa luta no tempo presente, Getúlio Vargas apresentou-se quase como um mártir que, como Tiradentes, se sacrificava pelo bem da nação. $\mathrm{O}$ presidente não foi sutil nessa comparação e, como uma ironia do destino, parecia antecipar sua entrada próxima no panteão dos mitos políticos brasileiros, no episódio trágico de sua morte, meses depois de ter estado em Ouro Preto:

Bem sei como a injustiça, a incompreensão e os processos difamatórios se agregam aos problemas, às dificuldades, as responsabilidades das grandes obras planejadas e empreendidas. [...] Deus é testemunha do quanto tenho feito, vencendo até os impulsos mais íntimos para amainar as paixões, apaziguar os espíritos, desarmar as prevenções, reunir a todos num só esforço pelo progresso do País. Nada me desviará dos rumos que eu tracei, porque as vozes agourentas não conseguem fazer do branco preto, nem convencem de isenção quando só procuram dissensão. Entendo que o 
governo é escola de humildade, aprendizado de disciplina, que exige a renúncia a si próprio e o domínio dos ressentimentos, para só cuidar dos interesses reais da Nação. (Estado de Minas, 1954, p.7).

Os afagos de Vargas dirigiam-se, então, para Minas Gerais, cujo governo demonstrava, naquele momento, apoio às suas posições. No discurso, o presidente apontava Minas como o lugar ideal para a busca do consenso e da harmonia, exaltando as tradições mineiras que poderiam serenar os espíritos exaltados daquele momento político delicado. Voltava-se, também ele, ao passado, e buscava em Tiradentes, mais uma vez, sustentação e legitimação. Os apelos nacionalistas vinham no momento dos mais duros embates entre Vargas e a oposição, quando acirrava seus ataques aos investidores estrangeiros e tentava a ampliação da base econômica estatal. Não permitir que os "interesses mesquinhos" se sobrepusessem aos interesses da nação seria a tarefa do governo, que deveria

[...] garantir a ordem, a liberdade, a coesão, a prosperidade econômica e a justiça social. [...] Para o seu pleno cumprimento não mediremos os sacrifícios. E aqui, neste dia glorioso, devemos renovar e revigorar esse irredutível propósito. O exemplo de Tiradentes e a lição de Minas nos darão força para construir no futuro um Brasil que corresponda aos sonhos do passado e em que se alcancem as esperanças do presente. (Estado de Minas, 1954, p.7).

Juscelino Kubitschek não parou por aqui a utilização da comemoração de 21 de abril como palanque. Mesmo depois de ter deixado o governo de Minas Gerais, seus sucessores, Clóvis Salgado e Bias Fortes, mantiveram a festa cívica e ainda deixaram espaço suficiente para que Kubitschek dela se apropriasse. Em 1955, já candidato à presidência da República, ele compareceu à cerimônia, desta vez como convidado do governador substituto, e não 
A comemoração do 21 de abril: o cenário do jogo político (1930-1960)

perdeu a oportunidade de construir as previsíveis associações entre o sacrifício de Tiradentes e as dificuldades enfrentadas durante a campanha presidencial. Nessa ocasião ele teria a honra de ser o primeiro a receber a Grande Medalha da Inconfidência, recentemente criada. A estratégia de dar projeção nacional à festa tinha, agora, um novo elemento na entrega das medalhas, para a qual eram escolhidas personalidades que ultrapassavam a atuação significativa somente em Minas Gerais.?

Juscelino Kubitschek discursou como candidato, e buscou jogar com as adversidades enfrentadas em sua campanha a fim de obter vantagens políticas. Ele próprio admitiria, anos depois, que os ataques que sofrera durante a campanha para a presidência da República foram transformados em trunfos que aumentaram sua popularidade (cf. Simões, 2000, p.30). Essa estratégia foi habilmente utilizada em seu pronunciamento como principal convidado das comemorações do dia de Tiradentes, em 1955:

Venho para dizer algumas palavras como orador oficial desta cerimônia em que todos os anos, neste quadro único, comovente, incomparável de Ouro Preto, se renovam as homenagens de gratidão e fidelidade ao mártir da Independência. Podeis bem avaliar nas circunstâncias em que me encontro, o ato solene e grave que é vir hoje a esta venerável cidade e dirigir-me ao grande homem humilde, perpetuado neste monumento que contemplamos agora, e mais do que nunca presente, nesta hora de incompreensão e dificuldades para a pátria que ele ajudou a fundar, regando com seu sangue generoso esta árvore ao mesmo tempo poderosa e frágil que é o Brasil. [...] Porque não estou em condições de fazer um discurso alusivo ao episódio da Inconfidência Mineira ou de falar à sombra de seu grande chefe, sem que me possua o desejo de examinar a minha consciência e proclamar as dúvidas que me assaltam, em relação ao acerto do destino, que colocou sobre os meus ombros, nesta fase crucial do Brasil, tão grandes, tão insuportáveis responsabilidades. Estarei em condições de 
assumir o papel de defensor das liberdades democráticas, tão ameaçadas mesmo, e principalmente por muitos que necessitam dessa liberdade para se poderem mover na superfície, na terra política, que procuram eles próprios afundar? [...] Quero, sob a evocação do Mártir do Brasil, diante dele, tomando-o como testemunha de minhas palavras, dizer-vos aqui, sinceramente, que eu não sabia o que teria que passar, de provações e sofrimento, e a verdadeira situação do Brasil, quando aceitei ser candidato à futura sucessão presidencial. $\mathrm{Na}$ verdade, o que tocava à necessidade de fomentar riqueza, de agir sem meios, medidas, para defender o país dos abusos e dificuldades, não me intimidava. A confiança, a fé, a esperança, tanto não me faltavam que desejei e aspirei disputar a eleição à suprema chefia da nação. (Estado de Minas, 1955, p.3-4).

A entrega de si, a humildade, o sacrifício a serviço de seu povo, eram idéias que calariam fundo no imaginário profundamente marcado pela religiosidade, e Juscelino Kubitschek colheria os frutos de sua apropriação. A modéstia e a demonstração da falta de ambições pessoais eram instrumentos eficazes na aproximação com o eleitorado e mostravam o "poder das palavras", como diria Balandier. Submetendo o seu destino, de um lado a Deus, de outro à intercessão do grande herói da nação, ele manejava com destreza elementos caros ao imaginário presente no universo cultural brasileiro, além de utilizar uma estratégia típica do populismo, a aproximação com as massas:

Se a Presidência da República me couber, interceda junto a Deus, Tiradentes, a esse Deus a cujos desígnios te submeteste com a resignação de um santo na hora extrema, pedelhe que me assista a fim de que eu possa realizar o meu sonho ardente de paz. Guia-me, ampare as minhas forças, pai da Independência, para que eu possa fazer algo em favor de nossa maior independência. [...] O Brasil que ainda não era Brasil completo no seu tempo, tu o levaste tão a 
A comemoração do 21 de abril: o cenário do jogo político (1930-1960)

sério que ofereceste a tua vida para redimi-lo, para dar-lhe soberania e independência. [...] Não hesitaste, não tremeste, não te exaltaste diante da morte e por isso és um exemplo de seriedade e dedicação. É nos conduzindo sempre com seriedade e dedicação no serviço da Pátria que honraremos a tua memória e seremos dignos de seu martírio. (Estado de Minas, 1955, p.3-4).

Juscelino Kubitschek foi eleito presidente e durante seu mandato só voltaria à Praça Tiradentes, em Ouro Preto, em 1960, às vésperas da inauguração de Brasília. A modalidade de comemoração por ele criada manteve-se, e a nova tradição foi tornando-se parte da agenda dos governos que lhe sucederam. Mesmo ausente das festas, Kubitschek era sempre mencionado nos discursos, e seus aliados cuidavam, com isso, de manter forte sua imagem de pioneiro e empreendedor. A imprensa também ajudava a manter o ex-governador em cena, lembrando, praticamente todos os anos, a importância de sua atuação na recuperação do prestígio da comemoração de 21 de abril e do culto a Tiradentes. Segundo o jornal Estado de Minas (1956, p.4), a partir de Kubitschek esse culto já não se confinava "ao ambiente das escolas primárias, como acontecia antigamente."

A festa adquiria, de maneira cada vez mais explícita, o caráter de fórum do debate político, o que podia ser aferido tanto nos editoriais dos jornais quanto nos discursos proferidos. Em 1956, por exemplo, a festa serviu às tomadas de posição frente à discussão sobre a adoção do parlamentarismo no Brasil. O governador Bias Fortes exortava seus ouvintes a buscarem na história as lições necessárias para combater os excessos que, em sua opinião, trairiam as mais sólidas tradições políticas brasileiras. O governador de Minas Gerais deixava de lado a Inconfidência Mineira para falar sobre o Império e as inconveniências do sistema parlamentarista, responsável, segundo ele, pelo atraso do Brasil no século XIX. 
A imprensa acompanhava o curso do debate e os dois principais jornais de Belo Horizonte seguiam o discurso conciliador, condenando as posições mais polarizadas que afloravam naquele final da década de 50. Naqueles anos Tiradentes emergia das sombras do passado e sua atuação era interpretada à luz dos interesses do presente. Suas representações eram apropriadas como exemplo de tudo aquilo que se considerava sob ameaça pelo acirramento do combate político. O editorial do Diário de Minas (1955, p.1) acusava aqueles que exaltavam a luta de Tiradentes pela liberdade, mas que na verdade tentavam "implantar o discricionarismo opressivo e que procuravam negar a justiça social, essa liberdade em nome da qual se prega o ódio, o divisionismo, a desarmonia." Eram grandes os receios em relação ao crescimento de alguns movimentos sociais, muitos deles ligados a grupos políticos de esquerda, o que representava, para os conservadores, a ameaça da implantação do comunismo. Novamente aparecia o velho fantasma a assombrar a nação.

Além dessa ameaça, sentia-se a nuvem da desagregação pairar sobre o cenário político. Tiradentes estaria sendo traído em suas pretensões de fraternidade e de unidade nacionais, e a comemoração do dia de sua morte deveria servir de estímulo à exterminação dessas forças desagregadoras. A liberdade pela qual lutara Tiradentes era vista como uma conquista do Brasil emancipado e vivenciada pelo regime democrático, escolhido pelo povo brasileiro, "convencido de que esta é a melhor forma de o Estado exercer o seu poder de coordenação e de unificação, enfim, a sua soberania." (Estado de Minas, 1958, p.4).

Apesar das tensões, em 1960 a comemoração do dia de Tiradentes ganhou especial colorido. A festa foi antecipada para o dia 18 de abril, pois no dia 21 seria inaugurada a nova capital da República, Brasília. Depois de alguns anos de ausência, Juscelino Kubitschek voltaria a Ouro Preto para ser, pela segunda vez, o orador oficial da cerimônia. Em seu discurso, o presidente se

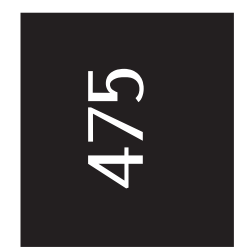


A comemoração do 21 de abril: o cenário do jogo político (1930-1960)

mostrava várias vezes vitorioso, e desta vez dedicou-se mais longamente ao homenageado do dia. Kubitschek discorreu sobre o sacrifício do herói nacional, sobre sua audácia e coragem em expressar suas idéias, em fazer a propaganda da revolução. Falou sobre o descrédito e o escárnio que se abateram sobre ele, e sobre sua perseverança na defesa de seus ideais. Para Juscelino, o heroísmo nasceria do amor às idéias, e "da aceitação dos sacrifícios decorrentes de tão entranhado sentir." Falando de Joaquim José da Silva Xavier ele falava de si próprio, preparando o terreno para aquilo que desejava, realmente, abordar: a grande realização de seu governo, a construção de Brasília.

Juscelino Kubitschek, que, em 1955, havia invocado a proteção de Tiradentes naquela mesma praça, vinha agora lhe render graças pela conquista, apropriando-se da imagem heróica do alferes mineiro para valorizar sua própria intrepidez na execução de tão ousado plano:

Brasileiros: compareço a este sítio dedicado a Tiradentes e habitado por sua presença invisível - numa hora de importância histórica para o nosso país. Estamos em luta para consolidar nossa independência econômica, para engrandecer, tornar firme e tranqüila a causa do Brasil, que custou o sacrifício àquele que consideramos nossa mais alta e pura encarnação do heroísmo patriótico. Começamos uma luta áspera para a plena utilização da herança que nos legaram os que construíram a unidade nacional. $\mathrm{O}$ povo brasileiro resolveu levar por diante essa campanha, até que se arranque grande parte de seu atraso crônico e aos sofrimentos a que está submetido, inclusive o da privação da liberdade, pois não há verdadeira liberdade onde reinam fome, doença, ignorância. Empreendemos esta luta e comprometemonos a vencê-la. [...] Passado um tempo em que a compreensão foi pouca, e as negações muitas e repetidas, Deus me deu a recompensa de ver-me apoiado pelo povo, além do que mereço. A nada mais aspiro senão, chegado o dia, 
passar o cargo ao meu sucessor. Não é uma missão de conveniência política, essa que almejo. Nosso país carece da união decorrente da consciência de termos todos, pelo nosso trabalho incessante e pela nossa nobre ambição, o dever de lhe acelerar o desenvolvimento a fim de que ele recupere o tempo perdido e torne efetiva e intocável a sua independência.

No próximo dia 21, com a instalação da nova Capital, vai iniciar-se uma era nova para o Brasil. Para esta venerável e gloriosa Ouro Preto, para esta festa da Pátria reconhecida

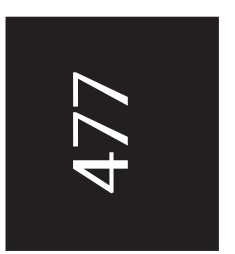
ao seu filho intimorato, para esta solenidade, a um tempo grave e jubilosa, em que se evoca o vulto luminoso de Tiradentes, converge agora o pensamento de todos os brasileiros, na reafirmação do nobre lema dos inconfidentes, que, nestes dias de luta pelo nosso desenvolvimento, adquire significado amplo e profundo: "Libertas quæ sera tamen". (Estado de Minas, 1960).

Kubitschek deixaria suas mais profundas reflexões para o dia da inauguração da nova capital, mas já em Ouro Preto fazia uso de duas idéias basilares nas representações de Tiradentes, isto é, o sacrifício e o heroísmo. O presidente não foi o primeiro e nem seria o último a se colocar numa posição similar ao do alferes condenado no século XVIII, mas talvez tenha sido o que melhor se apropriou dessas representações como mecanismo de legitimação de suas ações políticas. Juscelino Kubitschek, hábil na construção e manipulação de sua própria imagem, foi perspicaz na montagem das analogias que lhe eram úteis, quando ousava comparar-se ao herói republicano. Ele não deixaria de lado, também, as menções aos projetos de desenvolvimento.

Não bastasse a auto-exaltação de Kubitschek, o governador de Minas Gerais, promotor da festa, foi ainda menos sutil nas comparações elogiosas. Falando na "coincidência" da inauguração de Brasília com o dia de Tiradentes, Bias Fortes lembrava que a mudança da sede do governo do Brasil foi um dos postulados inscritos na bandeira dos insurretos de Vila Rica. Passavam ao largo de

Anos 90, Porto Alegre, v. 12, n. 21/22, p.437-486, jan./dez. 2005 
A comemoração do 21 de abril: o cenário do jogo político (1930-1960)

suas preocupações as questões da historiografia, de qual "país" falavam os inconfidentes, se de toda a América portuguesa ou apenas da capitania das Minas Gerais, quando pensavam na mudança da capital. Sua interpretação é que importava, para servir à legitimação e à valorização da obra do governo.

A inauguração de Brasília, "coincidentemente" no dia 21 de abril, foi lembrada em todo o país, basicamente nos mesmos termos desses pronunciamentos. ${ }^{10}$ No Rio de Janeiro, o Ministro da Guerra apontava esse fato como um "feliz presságio do muito que virá a representar para a redenção das vastas regiões do País, permitindo a melhor repartição da riqueza e concorrendo para que todos os brasileiros possam ter uma existência digna de ser vivida." (Jornal do Brasil, 1960, p.5). A idéia de progresso, recorrente no pensamento e na prática política brasileiros, sempre foi parte integrante do discurso alusivo à Inconfidência Mineira e ao idealismo de Tiradentes. Entre 1930 e 1960, várias foram as oportunidades nas quais obras públicas e empreendimentos econômicos foram saudados como realizações dos projetos da conspiração setecentista. Mas a inauguração de Brasília foi a que mais impacto causou e, mesmo para aqueles grupos intransigentes na oposição à empreitada de Kubitschek, foi quase obrigatória a ligação entre os dois mineiros. Enquanto uns engrandeciam historicamente a realização, outros a tratavam com ironia, negando ao presidente as honras prestadas a Tiradentes:

Todos os poderes da nação arranjaram as malas para a mudança e sua inauguração é trombeteada aos quatro cantos do mundo, através de desenfreada matéria que o sr. Juscelino Kubitschek distribuiu à imprensa nacional e estrangeira. Não serão, no entanto, fotografias coloridas e a bela arte de Niemeyer e Lúcio Costa que vão provar estar Brasília em condições de ser inaugurada. Trata-se de uma farsa, muito ao gosto de J.K. Um mérito, no entanto, não podemos negar ao Presidente da República: com a "inau- 
guração" de Brasília ele consegue, em 1960, fazer coincidir o $1^{\circ}$ de abril com a grande data de Tiradentes. (Jornal Binômio, 1960, p.1).

Mesmo no Rio de Janeiro, que perdia sua condição de capital da República, a chegada de Brasília era comemorada como uma realização com quase dois séculos de atraso. Se Tiradentes era um modelo que podia ser apropriado por quantos dele precisassem, essas apropriações estavam longe de ser uma unanimidade. Havia

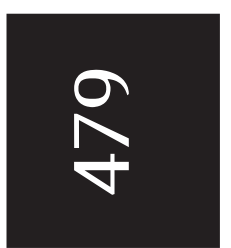
aqueles que viam com certa irritação as encenações levadas a efeito em Ouro Preto, todos os anos. Foram particularmente curiosos os comentários de um cronista do Diário de Minas, que assinava Rase'c, dizia ter sido dentista antes de jornalista e chamava Tiradentes de "meu colega". Rase'c via com ceticismo as pompas teatrais das comemorações oficiais do dia 21 de abril, e denunciava a hipocrisia dos que delas se utilizavam como propaganda política e auto-promoção. Apontava em suas crônicas as contradições entre os discursos e as práticas dos partidos e dos detentores do poder, e via vultosas semelhanças entre a situação do Brasil em finais do século XVIII e na década de 50 do século XX. Para ele, as questões de classe, que teriam levado Tiradentes à forca, ainda persistiam,

[...] os reinóis aí estão camuflados mas presentes, que no Brasil há uma aristocracia do poder, com famílias da nobreza cujos membros estão eternamente de cima, boiando sempre, mesmo com e apesar dos fictícios "golpes" e revoluções; sempre ouvi e li o nome dessas famílias eternas, e quando no cenário político surge um novo, não me iludo, procuro sempre entre seus parentes, vivos ou mortos, o senador, o ministro, o ex-presidente, o general, o conde, o barão... (Diário de Minas, 1950, p.2).

Mostrando-se impelido a escrever sobre o 21 de abril, "data gloriosa, para todos os que acreditam na vitória do espírito de luta 
A comemoração do 21 de abril: o cenário do jogo político (1930-1960)

contra a força aquilosante das más autoridades constituídas..." e atento ao patrulhamento fortemente presente nas práticas políticas da época, ele alertava, irônico, para o perigo de se fazer uma interpretação moderna de Tiradentes, pois

[...] os que acreditam na liberdade da pátria e na felicidade dos patrícios são grandes homens apenas depois de uma operação que pressuponho um tanto dolorosa: passar desta para a melhor, em alguns casos depois de colocarem entre sua cabeça e o tronco uma distância um tanto alongada, para o meu gosto... Tiradentes hoje é herói, porque está convenientemente morto. Se vivo estivesse, sua santa ira contra os desmandos da Metrópole poderiam acender-se de novo contra os mais criminosos ainda, contra os que saqueiam seus próprios patrícios. (Diário de Minas, 1952, p.2).

Vozes dissonantes em relação às comemorações se faziam ouvir também em jornais fora do circuito da "imprensa séria", como o jornal Binômio, reduto de jornalistas de esquerda. Em linguagem típica da imprensa nanica, políticos locais, convidados, laureados com a Medalha da Inconfidência, militares, eram alvo do sarcasmo dos articulistas do jornal, quando se tratava da festa de 21 de abril, "a pagodeira do governo". No Binômio, os oficiais de gabinete do governador eram os "rapazinhos suspeitos", que faziam pose para os estudantes da Escola de Minas, Juscelino Kubitschek reclamava da "esculhambação" na organização da lista dos laureados com a Medalha da Inconfidência, e o governador Bias Fortes nada mais fazia do que cumprir as ordens do presidente da República. A ira do jornal chegava às raias da vulgaridade e foi alvo da repressão, até ser fechado pelo governo militar, em 1964.

As comemorações de 21 de abril viveram momentos de grande vitalidade entre 1930 e 1960. No período de Getúlio Vargas elas foram adaptadas aos objetivos e às estratégias propagandísticas e cívicas, especialmente durante o Estado Novo. Juscelino 
Kubitschek daria a elas maior dinamismo, e embora aparentassem ser mais democráticas, não deixavam de ser também disciplinadas e hierarquizadas. Em ambos os momentos, no entanto, elas visariam, fundamentalmente, garantir a unidade nacional e procurar pelo consenso. Tiradentes seria, sempre, evocado como exemplo desses princípios, além de representar os ideais de liberdade e de progresso do país.

O 21 de abril, assim como outras festas cívicas, tornou-se um espetáculo do poder, a utilizar espaços, imagens e discursos na

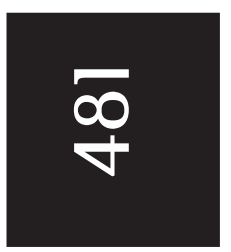
dramatização da política. O evento-espetáculo da execução de Tiradentes, ao ser comemorado, tornou-se o instrumento de outras celebrações espetaculares, por meio das quais seus realizadores travariam seus combates. Abusando da força dramática do alferes condenado à forca, executado e esquartejado em 1792, o poder político soube concentrar em discursos fracos e repetitivos, toda uma herança cultural e política, capaz de o legitimar. Isso foi possível porque, como afirma Balandier (1999, p.38),

[...] a manifestação da teatralidade do político, da sua sacralização e dos seus ritos, não é uma maneira oblíqua de o reduzir às aparências e a jogos ilusórios. É uma resultante - onde tudo converge -, desde as relações sociais que o sistema de produção define, até aos que são constituídos pelos valores e o imaginário colectivo.

\section{Celebration of April 21st the scenario of political game (1930-1960)}

Abstract. Civil celebrations and the incitation of patriotic feelings are particularly useful and efficacious in the political game as they deal with history and memory and may be at the core of the struggle for power. Civil celebration, a place of memory, first and foremost aims at the exaltation of nationality. This makes celebrating an event and a character regarded as meaningful for a nation's history their main objective most of the times. This paper deals with the celebration of April 21 $1^{\text {st }}$, the date dedicated to the memory of Inconfidencia Mineira, in Minas 
A comemoração do 21 de abril: o cenário do jogo político (1930-1960)

Gerais and Rio de Janeiro, as an instrument of propaganda and a legitimating device, mainly during the Getúlio Vargas' and Juscelino Kubtischek's rules between 1930 and 1960.

Keywords: Civil celebration. Propaganda. Inconfidência Mineira.

\section{Notas}

${ }^{1}$ Cabe lembrar que, mesmo sem o feriado, após 1930 era necessária autorização do Governo Provisório para que a comemoração fosse realizada em locais públicos.

${ }^{2}$ Não estou considerando aqui as importantes manifestações ocorridas em 1922, na ocasião das comemorações do centenário da Independência, quando a Inconfidência foi também lembrada. Mas ela insere-se em outro contexto político, fora das delimitações deste texto.

${ }^{3}$ O Centro Mineiro era uma agremiação de mineiros radicados no Rio de Janeiro e que, entre as atividades sociais e literárias, desenvolvia também as políticas, entre as quais se incluía a participação na organização das comemorações do 21 de abril naquela cidade.

${ }^{4}$ Sobre essa marca da passagem de Juscelino Kubitschek pelo cenário político brasileiro, do ponto de vista da construção de uma imagem vencedora e positiva, ver Simões (2000).

${ }^{5}$ Sobre alguns ritos políticos e sua relação com uma "valorização sacra do político", ver Rivière (1989).

${ }^{6}$ Falaram nessa sessão os representantes do PR, UDN, PRP, PDC, PTN, PTB e PSD.

${ }^{7}$ A Lei foi aprovada em julho de 1952 e regulamentada somente em 10 de março de 1955. Em abril desse ano, foi realizada a primeira cerimônia de condecoração, durante os festejos do 21 de abril, em Ouro Preto.

${ }^{8}$ Não é demais lembrar que JK fazia freqüentes alusões à sua cidade natal, Diamantina, como um local também ligado à Inconfidência Mineira, já que dali saíra um dos mais ilustres inconfidentes, o padre José da Silva e Oliveira Rolim.

${ }^{9}$ Nesta primeira cerimônia de entrega, foram laureados, além do ex-governador Kubitschek, o governador Clóvis Salgado; o Brigadeiro Eduardo Gomes; o exgovernador de Minas, Milton Campos; o General Cândido Rondon; o poeta Manoel Bandeira; o escritor Menotti Del Pichia; o escritor e historiador Augusto de Lima Júnior; a escritora Cecília Meireles; o prefeito de Belo Horizonte, Celso Mello de Azevedo; o escritor Carlos Drummond de Andrade; o Cônego Raimundo Trindade; Alceu Amoroso Lima; Salomão de Vasconcelos; José Lins do Rego; o maestro Camargo Guarnieri.

Anos 90, Porto Alegre, v. 12, n. 21/22, p.437-486, jan./dez. 2005 
${ }^{10} \mathrm{O}$ uso dessa data com o intuito de marcar outros eventos também foi notado na morte de Tancredo Neves, que para muitos teria sido "preparada" para acontecer nesse dia. Tem havido, desde então, muita polêmica, estimulada principalmente pela imprensa. Sobre as apropriações da morte de Tancredo Neves e sua associação com o dia 21 de abril e Tiradentes, ver Fonseca (2001).

\section{Referências}

AMARAL, Rubens do. As honras e os proveitos. Diário de Minas, Belo Horizonte, p. 4, 24 abr. 1930. Transcrito do Diário de São Paulo, 22 abr. 1930.

AUTOS de Devassa da Inconfidência Mineira. Belo Horizonte: Imprensa Oficial, 1977. V. 9.

AZEREDO NETTO. Das alterosas. Jornal do Brasil, Rio de Janeiro, p.13, 19 abr. 1932.

BALANDIER, Georges. O poder em cena. Coimbra: Minerva, 1999.

CAPELATO, Maria Helena Rolim. Multidões em cena; propaganda política no varguismo e no peronismo. Campinas, SP: Papirus, 1998.

COELHO, Hercídia Maria Facuri et al. Estado Novo, festa e memória. História, São Paulo, n.14, p. 97-109, 1995.

DIÁRIO DE MINAS. Olho de vidro - no dia de Tiradentes. Belo Horizonte: p.2, 21 abr. 1950.

Herói inútil. Belo Horizonte: p.2, 22 abr. 1952.

Tiradentes. Belo Horizonte: p.1, 21abr. 1955.

DUTRA, Eliana Regina de Freitas. Inconfidência Mineira: memória e contramemória. Varia História, Belo Horizonte, Departamento de História/UFMG, n.12, 1993.

Seminário Tiradentes, hoje: imaginário e política na República brasileira. Belo Horizonte: Fundação João Pinheiro; Centro de Estudos Históricos e Culturais, 1994.

Debate sobre o texto "1789: A idéia republicana e o imaginário das luzes”, de Maria Lúcia Montes. Seminário Tiradentes, boje: imaginário e política na República brasileira. Belo Horizonte: Fundação João Pinheiro; Centro de Estudos Históricos e Culturais, 1994. p.77-89.

Anos 90, Porto Alegre, v. 12, n. 21/22, p.437-486, jan./dez. 2005 
A comemoração do 21 de abril: o cenário do jogo político (1930-1960)

DUTRA, Eliana Regina de Freitas. O ardil totalitário. Imaginário político no Brasil dos anos 30. Rio de Janeiro; Belo Horizonte: Ed. UFRJ; Ed. UFMG, 1997.

ESTADO DE MINAS. Transferência das cinzas dos inconfidentes para Ouro Preto. Belo Horizonte: p.3, 21 abr. 1937a. . Comemoracõos do 21 de abril. Belo Horizonte: p.3, 21 abr. $1937 \mathrm{~b}$. Comemorações do 21 de abril (As cerimônias cívicas no Rio - Contraste Prisões em São Paulo). Belo Horizonte, p.1, 22 abr. 1937c. 5, 22 abr. 1938. Como foi cultuada nesta capital a memória de Tiradentes. Belo Horizonte: p.4A nação reverenciará amanhã a memória de Tiradentes. Belo Horizonte: p.4, 20 abr. 1941.

Toda a cidade comemorou ontem o Dia de Tiradentes. Belo Horizonte: p.3, 22 abr. 1942a.

As sentenças execrandas contra os Inconfidentes. Belo Horizonte: p.6, 28 abr. 1942b.

Preparam-se as comemorações do bicentenário de Gonzaga. Belo Horizonte: p.2, 21 abr. $1943 \mathrm{a}$.

Tiradentes, símbolo das nossas aspirações de democracia e liberdade. Belo Horizonte: p.3, 21 abr. 1943 b.

Grandioso meeting em homenagem ao mártir da Liberdade. Belo Horizonte: p.3, 19 abr. 1945 a.

A luta pela liberdade. Belo Horizonte: p.2, 21 abr. 1945b.

Imponente celebração no próprio cenário da Conjuração Mineira. Belo Horizonte, p.3, 16 abr. 1952a.

Oradores de todos os partidos falaram ontem sobre a passagem do Dia de Tiradentes. Belo Horizonte, p.3, 23 abr. 1952b. abr. 1952c.

Projeto de lei instituindo a Medalha da Inconfidência. Belo Horizonte: p.7, 23

Não preservam o regime os que engendram ardis para fraudar a vontade do povo. Belo Horizonte: p.7, 23 abr. 1954. Discurso do presidente Getúlio Vargas.

Juscelino em Ouro Preto invoca para a sua causa a proteção de Tiradentes. Belo Horizonte: p.3-4, 23 abr. 1955. Discurso do ex-governador Juscelino Kubitschek.

Anos 90, Porto Alegre, v. 12, n. 21/22, p.437-486, jan./dez. 2005 
Thais Nivia de Lima e Fonseca

ESTADO DE MINAS. Vinte e um de abril. Belo Horizonte: p.4, 21 e 22 abr. 1956.

Vila Rica. Belo Horizonte: p.4, 20 abr. 1958. p. 4.

Acima de partidos está o interesse da coletividade. Belo Horizonte: p.1, 11, 19 abr. 1960. Discurso do presidente Juscelino Kubitschek.

FONSECA, Thais Nivia de Lima e. Mediadores da memória: a Inconfidência Mineira na Praça Tiradentes de Ouro Preto. In: SIMPÓSIO NACIONAL DE HISTÓRIA-ANPUH, XX, Florianópolis, 1999. Anais... 1999.

Festas cívicas e universo cultural: Minas Gerais no século XIX. In: PAIVA, Eduardo França; ANASTASIA, Carla Maria Junho (Org.). O trabalho mestiço; maneiras de pensar e formas de viver - séculos XVI a XIX. São Paulo: Annablume; PPGH/UFMG, 2002.

Da infâmia ao altar da pátria: memória e representações da Inconfidência Mineira e de Tiradentes. 2001. Tese (Doutorado em História Social) - Faculdade de Filosofia, Letras e Ciências Humanas, Universidade de São Paulo, São Paulo, 2001.

JEANNENEY, Jean-Noël. A mídia. In: RÉMOND, René (Org). Por uma história política. Rio de Janeiro: Editora UFRJ, 1996.

JORNAL BINÔMIO. $1^{\circ}$ de Abril. Belo Horizonte: p.1, 18 abr. 1960.

JORNAL DO BRASIL. Uma grande data nacional. Rio de Janeiro: p.11, 20 abr. 1932a.

Grandiosa parada de civismo. Rio de Janeiro: p.10-11, 22 abr. 1932b.

1937.

Uma das datas máximas da história nacional. Rio de Janeiro: p.8, 21 abr.

Tiradentes. Rio de Janeiro: p.7, 21 abr. 1939.

Ordem do dia do Ministro lida nos quartéis saúda a inanguração de Brasília. Rio de Janeiro: p.5, 21 abr. 1960.

KUBITSCHEK, Juscelino. Realidades, perspectivas. Discursos. Belo Horizonte: Publicações da Secretaria da Educação do Estado de Minas Gerais, [s.d].

LINHARES, Joaquim Nabuco. Itinerário da imprensa de Belo Horizonte: 1895/1954; estudo crítico e nota biográfica de Maria Ceres Pimenta S. Castro. Belo Horizonte: Fundação João Pinheiro, 1995.

Anos 90, Porto Alegre, v. 12, n. 21/22, p.437-486, jan./dez. 2005 
A comemoração do 21 de abril: o cenário do jogo político (1930-1960)

RAYNAUD, Philippe. La commémoration: illusion ou artifice? Le Débat, n.78, p. 104-115, jan./fev. 1994.

RIVIÈRE, Claude. As liturgias políticas. Rio de Janeiro: Imago, 1989.

ROMANO, Roberto. Brasil; Igreja contra Estado. São Paulo: Kairós, 1979.

SCHEMES, Claudia. Festas cívicas e esportivas no populismo: um estudo comparativo dos governos Vargas (1937-1945) e Perón (1946-1955). 1995. Dissertação

(Mestrado em História Social) - FFLCH, Universidade de São Paulo, São Paulo, 1995.

SIMÕES, Josanne Guerra. Sirênico canto: Juscelino Kubitschek e a construção de uma imagem. Belo Horizonte: Autêntica, 2000.

TOSCANO, Verónica Zárate. Discurso cívicos y memoria histórica en el México del siglo XIX. Trabalho apresentado no Séminaire Cultures et sociétés de l'Amérique coloniale, $\mathrm{XVI}^{\mathrm{e}}-\mathrm{XX}^{\mathrm{e}}$ siècle, Paris, École des Hautes Études en Sciences Sociales, 2001. Mimeografado.

Recebido em 24/06/2004.

Aprovado em 21/06/2005. 